OPEN ACCESS

Edited by:

Andrea Gomez-Zavaglia,

National Scientific and Technical

Research Council, Argentina

Reviewed by:

E. Emma Tymczyszyn,

National Scientific and Technical

Research Council, Argentina

Jose Antonio Curiel,

Instituto de Ciencias de la Vid y del

Vino, Spain

${ }^{*}$ Correspondence: Joaquín Bautista-Gallego

joaquin.bautista@urv.cat

Specialty section:

This article was submitted to

Food Microbiology,

a section of the journal

Frontiers in Microbiology

Received: 08 August 2016 Accepted: 16 September 2016

Published: 30 September 2016

Citation:

Margalef-Català M, Araque I, Bordons A, Reguant $C$ and

Bautista-Gallego J (2016)

Transcriptomic and Proteomic

Analysis of Oenococcus oeni

Adaptation to Wine Stress Conditions.

Front. Microbiol. 7:1554

doi: 10.3389/fmicb.2016.01554

\section{Transcriptomic and Proteomic Analysis of Oenococcus oeni Adaptation to Wine Stress Conditions}

\author{
Mar Margalef-Català, Isabel Araque, Albert Bordons, Cristina Reguant and \\ Joaquín Bautista-Gallego * \\ Departament de Bioquímica i Biotecnologia, Facultat d'Enologia, Universitat Rovira i Virgili, Tarragona, Spain
}

Oenococcus oeni, the main lactic acid bacteria responsible for malolactic fermentation in wine, has to adapt to stressful conditions, such as low $\mathrm{pH}$ and high ethanol content. In this study, the changes in the transcriptome and the proteome of $O$. oeni PSU-1 during the adaptation period before MLF start have been studied. DNA microarrays were used for the transcriptomic analysis and two complementary proteomic techniques, 2-D DIGE and iTRAQ labeling were used to analyze the proteomic response. One of the most influenced functions in PSU-1 due to inoculation into wine-like medium (WLM) was translation, showing the over-expression of certain ribosomal genes and the corresponding proteins. Amino acid metabolism and transport was also altered and several peptidases were up regulated both at gene and protein level. Certain proteins involved in glutamine and glutamate metabolism showed an increased abundance revealing the key role of nitrogen uptake under stressful conditions. A strong transcriptional inhibition of carbohydrate metabolism related genes was observed. On the other hand, the transcriptional up-regulation of malate transport and citrate consumption was indicative of the use of L-malate and citrate associated to stress response and as an alternative energy source to sugar metabolism. Regarding the stress mechanisms, our results support the relevance of the thioredoxin and glutathione systems in the adaptation of $O$. oeni to wine related stress. Genes and proteins related to cell wall showed also significant changes indicating the relevance of the cell envelop as protective barrier to environmental stress. The differences found between transcriptomic and proteomic data suggested the relevance of post-transcriptional mechanisms and the complexity of the stress response in $O$. oeni adaptation. Further research should deepen into the metabolisms mostly altered due to wine conditions to elucidate the role of each mechanism in the O. oeni ability to develop MLF.

Keywords: Oenococcus oeni, malolactic fermentation, transcriptomic, proteomic, stress, wine

\section{INTRODUCTION}

Malolactic fermentation (MLF) occurs in wine spontaneously and, alternatively, can be induced inoculating selected strains of lactic acid bacterium (LAB), mainly Oenococcus oeni, usually after alcoholic fermentation (Betteridge et al., 2015). The wide range of physiological characteristics and the ability to cope with several environmental stresses make $O$. oeni the main responsible for MLF. 
This process consists in the conversion of L-malate to $\mathrm{L}-(+)$ lactate and $\mathrm{CO}_{2}$ and is required in wine, mainly from red grape varieties, because it confers positive sensory traits and improves wine's microbiological stability (Lonvaud-Funel, 1999; Mills et al., 2005).

Wine is a harsh environment for $O$. oeni due to its physicochemical characteristics, such as low $\mathrm{pH}$, ethanol and $\mathrm{SO}_{2}$ content, which can negatively affect bacterial survival and consequently MLF development. In contrast to the diversity of stress response mechanisms described in Bacillus subtilis (Hecker et al., 1996; Hecker and Völker, 1998), the model organism for Gram-positive bacteria, no gene encoding an alternative sigma factor or any other known regulator of stress response, such as HrcA, could be identified in O. oeni. Grandvalet et al. (2005) described in $O$. oeni the CtsR as the regulator for most of molecular chaperone genes. Different studies have characterized some of the stress response genes in $O$. oeni, such as clp, grpE, groES, $h s p 18, h d c, f t s H$, omrA, $c f a, a t p B$, and $\operatorname{tr} x A$, among others (Jobin et al., 1997; Guzzo et al., 2000; Bourdineaud et al., 2003, 2004; Beltramo et al., 2004, 2006; Bourdineaud, 2006; Spano and Massa, 2006; Olguín et al., 2009, 2010). These studies revealed that $O$. oen $i$ has developed cellular mechanisms that make it more resistant to adverse conditions than other LAB species (Beltramo et al., 2006). The knowledge of the stress response machinery of this bacterium is key to understand the ability of adaptation to wine environment of each strain and select the best starter culture.

Thanks to the publication over the recent years of the genomes of different O. oeni strains in the National Center for Biotechnology Information (NCBI), nowadays it is possible the global study of stress response by "omics" technologies. There are two published studies of $O$. oeni combining transcriptomic and proteomic analysis, applying DNA microarrays and 2DE or 2DDIGE: Olguín et al. (2015) studied the effect of ethanol addition during growth (after $1 \mathrm{~h}$ ), and Costantini et al. (2015) studied wine like media adaptation during $24 \mathrm{~h}$. The first proteomic study was from Silveira et al. (2004) and showed that both ethanol stress and adaptation significantly changed the protein profiles of O. oeni cells. Later, Cecconi et al. (2009) performed a proteomic study using $2 \mathrm{DE}$ examining $O$. oeni adaptation to wine conditions. Other authors have studied oenological starters to determine their proteomic profile (Cafaro et al., 2014; Napoli et al., 2014).

In this work, we combined a transcriptomic and proteomic approach to elucidate the changes involved in the adaptation of O. oeni PSU-1 to wine-like conditions, evaluating the period between the inoculation and the beginning of MLF. The transcriptomic analysis was developed using DNA microarrays designed for PSU-1 strain and the results obtained were validated by real-time qPCR. For the proteomic study two complementary techniques were employed: 2D-DIGE and iTRAQ labeling. 2DDIGE technique (Unlü et al., 1997) relies on a pre-electrophoretic labeling, allowing sample multiplexing in the same gel. This gel-dependent technique has been used in several studies with other LAB species (Mehmeti et al., 2011; Koponen et al., 2012; Genovese et al., 2013). However, the variable reproducibility of this technique along with the difficult automation and detection of low abundance and membrane hydrophobic proteins have led to a wide variety of off-gel methodologies for protein quantification. In order to complement DIGE analysis, in this work it was used a tandem mass spectrometry (MS/MS) coupled with isobaric tags for relative and absolute quantification (iTRAQ) (Ross et al., 2004) labeling to enable the identification and quantification of differentially expressed proteins in specific times. The combination of liquid chromatography (LC) and electrospray ionization MS/MS analysis is an emerging powerful methodology enabling quantification and comparison of protein levels directly from samples with greater efficiency and accuracy. This is the first proteomic analysis using this gel-free technique with O. oeni.

\section{MATERIALS AND METHODS}

\section{Growth Conditions and MLF Monitoring}

The strain used in this study was O. oeni PSU-1, the only in its species with the genome fully annotated (Mills et al., 2005). Stock cultures (kept frozen at $-80^{\circ} \mathrm{C}$ ) were grown in MRS broth medium (De Man et al., 1960) supplemented with $4 \mathrm{~g} / \mathrm{L}$ $\mathrm{L}$-malic acid and $5 \mathrm{~g} / \mathrm{L}$ fructose at $\mathrm{pH} 5.0$ at $28^{\circ} \mathrm{C}$ in a $10 \% \mathrm{CO}_{2}$ atmosphere. Cells were collected at the end of the exponential phase $\left(\mathrm{OD}_{600 \mathrm{~nm}}=1.4-1.6\right)$ and inoculated into the medium. Then, cells were harvested at the end of the exponential phase and inoculated $(2 \% \mathrm{v} / \mathrm{v})$ into $5 \mathrm{~L}$ screw-cap bottles of winelike medium (WLM). WLM was prepared following (Bordas et al., 2015) containing $12 \%$ ethanol (v/v) at $\mathrm{pH} 3.4$. The bottles were incubated at $20^{\circ} \mathrm{C}$. The assays were run in triplicate. Measurements of L-malic acid consumption were performed with the multianalyser Miura One (I.S.E. S.r.l, Guidonia, Italy) and the enzymatic kit ready to use (TDI SL, Barcelona, Spain) in order to determine the beginning and evolution of MLF.

\section{RNA and Protein Extraction}

After the inoculation into WLM, samples at different times $(0,0.5,1,2,4,6$, and $8 \mathrm{~h})$ were taken for RNA and protein extraction. For RNA extraction, $20 \mathrm{~mL}$ were collected from WLM, or $0.3 \mathrm{~mL}$ from MRS culture used for inoculation $(0 \mathrm{~h})$. Samples were centrifuged at $10,000 \times g$ for $5 \mathrm{~min}$ at $4{ }^{\circ} \mathrm{C}$, supernatant was removed and pellet was washed with $10 \mathrm{mM}$ Tris- $\mathrm{HCl}$ prepared with diethylpyrocarbonate-treated water (DEPC), and then frozen in liquid nitrogen and kept at $-80^{\circ} \mathrm{C}$ until RNA extraction. High Pure RNA Isolation Kit (Roche, Mannheim, Germany) was used for RNA extraction following the instructions of the manufacturer with some modifications, such as lysis with lysozyme dissolved in $10 \mathrm{mM}$ Tris- $\mathrm{HCl}$ buffer DEPC, at $50 \mathrm{mg} / \mathrm{mL}$ during $30 \mathrm{~min}$ at $37^{\circ} \mathrm{C}$. RNA was treated with Turbo DNA-free (Life Technologies, USA). Total acid nucleic concentrations were calculated using a Nanodrop 1000 spectrophotometer (Thermo Fisher Scientific, Bremen, Germany).

For protein extract preparation, $800 \mathrm{~mL}$ of WLM, or $35 \mathrm{~mL}$ from MRS culture used for inoculation $(0 \mathrm{~h})$, were centrifuged at $5000 \times g \mathrm{rpm}$ for $15 \mathrm{~min}$. Supernatant was removed and pellet was washed twice with $10 \mathrm{mM}$ Tris- $\mathrm{HCl}$ buffer at $\mathrm{pH} 8$, frozen in liquid nitrogen and kept at $-80^{\circ} \mathrm{C}$ until protein extraction. 
Cell pellets were then resuspended to a final $\mathrm{OD}_{600}=30$ in a solution of $0.1 \mathrm{M}$ Tris- $\mathrm{HCl}$ at $\mathrm{pH} 7.5$, mixed with protease inhibitor cocktail from Roche. Cells were disrupted using Oneshot disruptor (Constant Systems Ltd.) at $5^{\circ} \mathrm{C}$, applying twice a $2.7 \mathrm{kbar}$ pressure. Protein suspension was centrifuged at $4500 \times$ $g$ for $15 \mathrm{~min}$ at $4^{\circ} \mathrm{C}$ to remove cell debris and the supernatant was frozen in liquid nitrogen until protein analysis.

\section{Transcriptomic Analysis DNA Microarray Description, Labeling, and Hybridization}

Microarrays (090324_Oenococcus oeni expression 4-plex array), based on PSU-1 genome, were developed by Roche NimbleGen (Madison, WI, USA) and samples were analyzed at the Functional Genomics Core of the Institute for Research in Biomedicine (IRB, Barcelona, Spain) as described by Olguín et al. (2015). The results were submitted to GEO (Gene Expression Omnibus Database, NCBI) under accession number GSE85137.

\section{Microarray Results Validation by Real-Time qPCR}

Nucleotide sequences of O. oeni strain PSU-1 (NC_008528) were obtained from the NCBI. Several genes were selected for real-time qPCR validation of the microarray data. The primers used for these analyses are shown in Table 1. Some genes were selected due to their involvement in stress response according to previous studies (Jobin et al., 1999b; Beltramo et al., 2006; Olguín et al., 2009; Bordas et al., 2013; Margalef-Català et al., 2017) and others were randomly selected with the sole objective of validating the methodology. Reverse transcription, real-time qPCR and primer design were performed according to Olguín et al. (2009). The Primer Express ${ }^{\circledR}$ Software was used to select primer sequences and analyze secondary structures and dimer formation. The absence of chromosomal DNA contamination was confirmed by qPCR. For the normalization of qPCR data (Vandesompele et al., 2002; Sumby et al., 2012; Cafaro et al., 2014) four genes (ldhD, dpoIII, gyrA, and $g y r B$ ) were evaluated as internal controls, using the primers described in Table 1. Of these, $l d h D$ and gyrA genes showed the lowest variation under the experimental conditions used (data not shown) and were chosen as internal controls. The amplification efficiency was calculated as in Olguín et al. (2015).

\section{Proteomic Analysis 2D-DIGE}

Protein extracts were analyzed in the Center for Omic Sciences from Servei de Recursos Cientifics $i$ Tècnics of University Rovira i Virgili (Reus, Spain). Proteins were precipitated using TCA/Acetone, and the pellet was resuspended in $200 \mu \mathrm{L}$ of rehydration buffer (7 M urea, $2 \mathrm{M}$ thiourea, 4\% CHAPS, $30 \mathrm{mM}$ Tris-base) at final $\mathrm{pH}$ 8.5. The samples were quantified using Bradford and stored at $-20^{\circ} \mathrm{C}$. Fifty microgram of each protein sample was minimally labeled with $400 \mathrm{pmol}$ of either Cy3 or Cy5 (N-hydroxy succinimidyl ester-derivatives of the cyanine dyes). To facilitate image matching and cross-gel normalization, an internal standard was made pooling all samples and labeling with Cy2 at the same ratio (50 $\mu \mathrm{g}: 400$ pmols). Hence, two samples and the internal standard could be run in the same gel and quantified on multiple 2-DE. Labeling reactions were performed on ice and darkness during $30 \mathrm{~min}$ and quenched using an excess of free L-lysine.

Isoelectrofocusing (IEF) was carried out using $24 \mathrm{~cm}$ Immobiline Dry-strips ( $\mathrm{pH}$ interval 4-7, nonlinear, GE Healthcare), and sample was loaded by two rehydration steps (passively for $5 \mathrm{~h}$ at $20^{\circ} \mathrm{C}$, and actively at $50 \mathrm{~V}$ during $12 \mathrm{~h}$ in an Ettan IPGphor 3 system from GE Healthcare). IEF migration program started focusing $500 \mathrm{~V}$ for $7 \mathrm{~h}$, ramping until $1 \mathrm{KV}$ during $4 \mathrm{~h}$ and ramping again until $10 \mathrm{KV}$ during $3 \mathrm{~h}$, and finally a step maintained at $10 \mathrm{KV}$ to reach $70 \mathrm{KVh}$. Strips were then equilibrated for $15 \mathrm{~min}$ in a $50 \mathrm{mM}$ Tris- $\mathrm{HCl}(\mathrm{pH} 8.8) 6 \mathrm{M}$ urea, $30 \%$ glycerol and 2\% SDS buffer, adding first 1\% DTT, and in a second time supplemented with $4 \%$ iodoacetamine (Görg et al., 2004).

\section{Imaging and data processing}

Gels were scanned using a PharosFX ${ }^{\mathrm{TM}}$ Plus Molecular Imager and analyzed using Progenesis Same Spots Analysis Software v4.5 (Totallab). Spots displaying a $\geq 1$ average-fold increase or decrease in abundance with a $p<0.05$ were selected for protein identification. Features detected from non-protein sources (e.g., dust particles and dirty backgrounds) were filtered out. Picking analysis was carried loading $720 \mu \mathrm{g}$ of the internal standard mix without labeling in a 2DE gel as described above. Gels were stained with Coomassie blue G250 and imaged using Pharos FXTM Plus Molecular Imager from BioRad using Quantity One version 4.6.9 software.

\section{In gel-trypsin digestion and MS-Based protein identification}

Spots of interest were automatically excised from 2-DE gels using the ExquestTM Spot Cutter with the PDQuestTM Advanced 2D Analysis Software V8.0.1 both from Bio-Rad. Excised spots were de-hydrated by extensive washings with $25 \mathrm{mM}$ ammonium bicarbonate and acetonitrile. All gel pieces were incubated with $15 \mathrm{ng} / \mu \mathrm{L}$ sequencing-grade trypsin in $50 \mathrm{mM}$ ammonium bicarbonate at $\mathrm{pH} 7.9$ overnight at $37^{\circ} \mathrm{C}$. Following digestion, the peptides were desalted using $\mathrm{C} 18$ ziptip (Millipore), and eluted with $75 \% \mathrm{ACN}+0.1 \%$ Trifluoroacetic acid.

Peptides were spotted onto an HTP BigAnchor 384 (Bruker) target using $\alpha$-cyano-4-hydroxy-cinnamic acid as matrix and were analyzed on a MALDI TOF/TOF (Ultraflextreme, Bruker Daltonics, Bremen, Germany) instrument operated in the positive ion mode. All mass spectra were calibrated externally with the Peptide Calibration Standard I from Bruker. The analyzed mass range was 600-3500 Da. MS and MS/MS analyses were performed automatically. For MS analysis, 3100 satisfactory shots were accumulated by recording 100 -shot steps at 20 random positions using fuzzy control laser attenuation between 40 and 100\% at initial and maximal power respectively. For MS/MS 3100 satisfactory shots were accumulated by recording 100-shot steps and 4000 for the fragment ion spectra.

MS and tandem MS/MS spectra were searched by Protein Scape v: 3.0.0 446 using MASCOT (Matrix Science Inc., MA, 2.4.0) against NCBInr database (46742655 entries) restricted to Bacteria (Eubacteria). The search parameters were set to: MS accuracy $20 \mathrm{ppm}$, MS/MS accuracy $0.5 \mathrm{Da}$, two missed 
TABLE 1 | Gene descriptions and the corresponding primer sequences used for validation of microarray results by real-time qPCR.

\begin{tabular}{llll}
\hline $\begin{array}{l}\text { Gene symbol and } \\
\text { old tag (OEOE_) }\end{array}$ & $\begin{array}{l}\text { Sequence } \\
\left(5^{\prime}-3^{\prime}\right)\end{array}$ & Amplicon & References $^{\text {length (bp) }}$
\end{tabular}

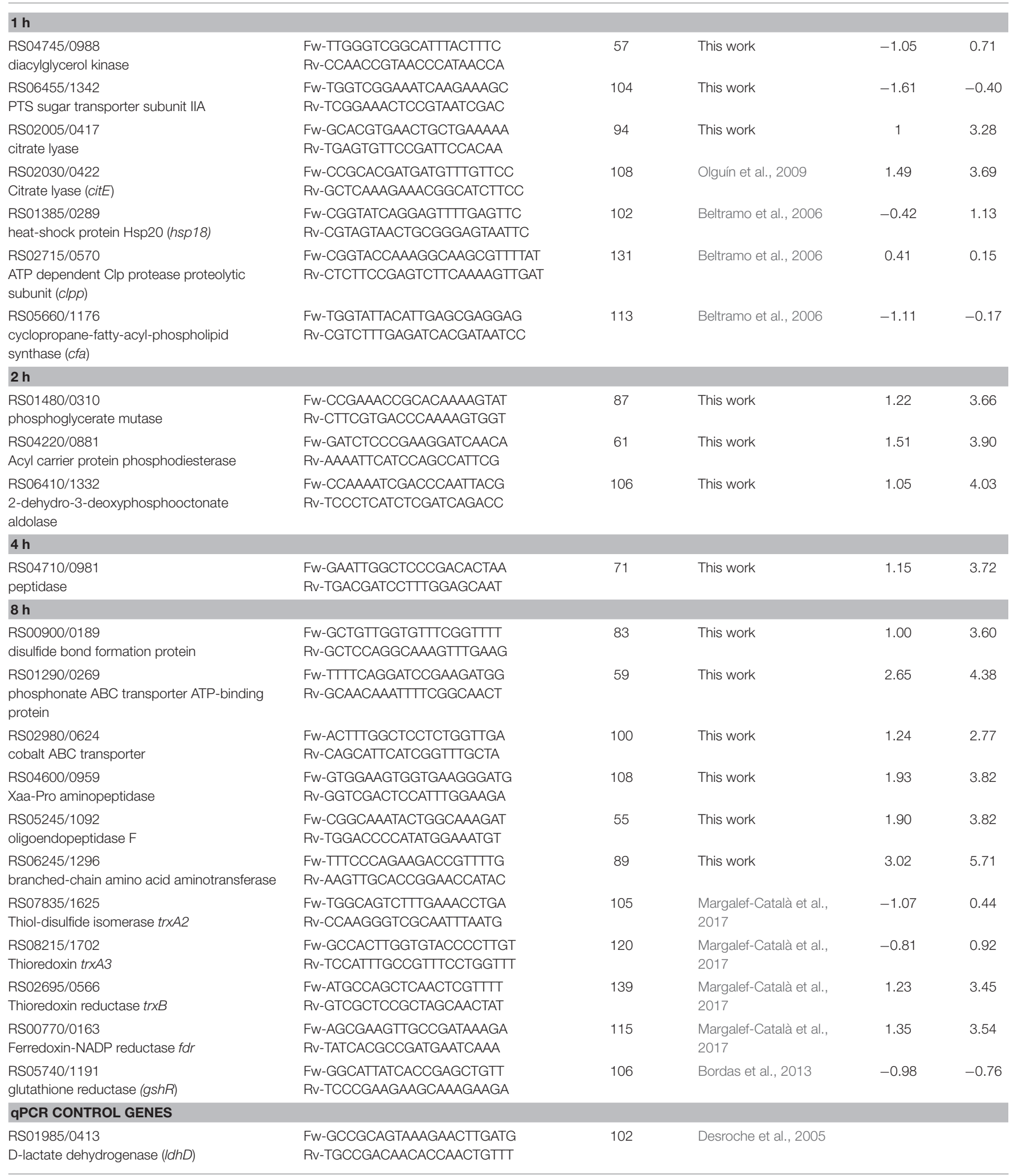


TABLE 1 | Continued

\begin{tabular}{|c|c|c|c|c|c|}
\hline $\begin{array}{l}\text { Gene symbol and } \\
\text { old tag (OEOE_) }\end{array}$ & $\begin{array}{l}\text { Sequence } \\
\left(5^{\prime}-3^{\prime}\right)\end{array}$ & $\begin{array}{l}\text { Amplicon } \\
\text { length (bp) }\end{array}$ & References & Microarray ${ }^{a}$ & $q P^{\prime} R^{b}$ \\
\hline $\begin{array}{l}\text { RSO4805/1000 } \\
\text { DNA polymerase III subunit alpha } \\
\text { (dpollI) }\end{array}$ & $\begin{array}{l}\text { Fw-AATTCGCACGGATTGTTTC } \\
\text { Rv-GCGAACCAGCATAGGTCAAT }\end{array}$ & 103 & Stefanelli, 2014 & & \\
\hline $\begin{array}{l}\text { RS04780/0995 } \\
\text { DNA primase (dna G) }\end{array}$ & $\begin{array}{l}\text { Fw-TGTGGACGGAGTGGCAATGT } \\
\text { Rv-CAGTATTTCTGTATATTACTATCG }\end{array}$ & 127 & $\begin{array}{l}\text { Desroche et al., } 2005 \\
\text { Margalef-Català et al., } \\
2017\end{array}$ & & \\
\hline $\begin{array}{l}\text { RS00025/0005 } \\
\text { DNA gyrase subunitB (gyrB) }\end{array}$ & $\begin{array}{l}\text { Fw-GAGGATGTCCGAGAAGGAATTA } \\
\text { Rv-ACCTGCTGGGCATCTGTATTG }\end{array}$ & 107 & $\begin{array}{l}\text { Desroche et al., } 2005 \\
\text { Margalef-Català et al., } \\
2017\end{array}$ & & \\
\hline
\end{tabular}

RNA samples were taken at signaled times, where maximum over- or under- expression had been observed in microarray assay.

${ }^{a}$ Microarray.

${ }^{b} R T-q P C R$ fold changes between: $t=0 \mathrm{~h}$ and $t$ in which there is the maximum expression or inhibition after the inoculation.

cleavage by trypsin allowed, carbamidomethylation of cysteine as fixed modification and oxidation of methionine and N-terminal amino acid conversion of glu and gln to pyroglutamic acid as variable modification. Significant protein hits (for peptide mass fingerprinting $p \leq 0.05$ and for MS/MS at least two peptides with $p \leq 0.05$, and protein scores greater than 30 ) were considered significant.

\section{iTRAQ Labeling}

\section{Protein digestion and $i T R A Q$ labeling}

On a SDS-PAGE gel (12\% resolving gel and $4 \%$ stacking gel) at $20 \mathrm{~mA} /$ gel $40 \mu \mathrm{g}$ total protein per sample were run. The electrophoresis was stopped when the front dye had barely passed from the stacking gel into the resolving gel, and a unique concentrated band was obtained for every sample, which was stained using Coomassie Brilliant Blue G-250, excised, cut into small pieces and stored at $4^{\circ} \mathrm{C}$ in ultrapure water.

Protein digestion was performed according to Shevchenko et al. (1996) with minor variations as described before. Proteins were reduced using $5 \mathrm{mM}$ tris(2-carboxyethyl)phosphine (TCEP) in $50 \mathrm{mM}$ triethylammonium bicarbonate $\mathrm{pH} 7.9$ during $1 \mathrm{~h}$ at $60^{\circ} \mathrm{C}$ and alkylated with $10 \mathrm{mM}$ methyl methanethiosulfate (MMTS) in the same buffer during $30 \mathrm{~min}$ at room temperature. To digest the samples, they were incubated with $15.4 \mathrm{ng} / \mu \mathrm{L}$ sequencing-grade trypsin in $50 \mathrm{mM}$ triethylammonium bicarbonate at $\mathrm{pH} 7.9$ overnight at $37^{\circ} \mathrm{C}$. After digestion, the peptides were extracted from gel by elution in a mixture of $50 \%$ acetonitrile $5 \%$ formic acid. Tryptic peptides were dried by SpeedVac and re-suspended in $30 \mu \mathrm{L}$ TEAB $0.5 \mathrm{M}$ at $\mathrm{pH} 8.5$.

iTRAQ-8plex labeling reagents (AB SCIEX) were added to each peptide samples according manufacturer's instructions and incubated at room temperature for $120 \mathrm{~min}$. Mixtures of labeled samples were washed from unreacted reagents using SCX column (Strata ${ }^{\circledR}$ SCX $55 \mu \mathrm{m}, 70 \AA$, Phenomenex) in $10 \mathrm{mM}$ phosphoric acid, $25 \%$ acetonitrile, $\mathrm{pH} 3$ as binding buffer and $5 \%$ ammonium hydroxide, $25 \%$ acetonitrile for the elution. After the elution, samples were vacuum dried and re-suspended in water for the next step.

\section{Sample fractionation and mass spectrometry analysis (LC-MS/MS)}

Pooled peptides were separated in an Agilent 3100 OFFGEL Fractionator (Agilent Technologies, Santa Clara, CA) through 24-well IPG strips (linear gradient from $\mathrm{pH}$ 3-10) according to the supplier's protocol. After separation, fractions were desalted and concentrated through C18 Sep-Pak column (Waters, Bedford, MA) previously to LC-MS/MS detection.

A nano LC II coupled to an LTQ-Orbitrap Velos Pro mass analyzer, both from Thermo Scientific (Bremen, Germany), was used for peptide analysis. The chromatographic separation was achieved using a nanoLC $\mathrm{C}_{18}$ trap column (100 $\mu \mathrm{m}$ I.D.; $2 \mathrm{~cm}$ length; $5 \mu \mathrm{m}$ particle diameter, Thermo Fisher Scientific) coupled to a nanoLC $\mathrm{C}_{18}$ analytical column $(75 \mu \mathrm{m}$ I.D.; $15 \mathrm{~cm}$ length; $3 \mu \mathrm{m}$ particle diameter, Nikkyo Technos Co. LTD, Japan) under gradient elution conditions. Ultrapure water with $0.1 \% \mathrm{HCOOH}$ (solvent A) and acetonitrile with $0.1 \% \mathrm{HCOOH}$ (solvent B) was the mobile phase and the gradient consisted of $0-5 \% \mathrm{~B}$ during $5 \mathrm{~min}, 5-35 \%$ B $30 \mathrm{~min}, 35-80 \%$ B $15 \mathrm{~min}$ and $80-100 \%$ B $12 \mathrm{~min}$, and finally is maintained at $100 \% \mathrm{~B}$ during $10 \mathrm{~min}$. A flow rate of $300 \mathrm{~nL} / \mathrm{min}$ was used to elute peptides for real time ionization on a nanoFlex electrospray ion source from Thermo Fisher Scientific.

MS measurements detected intact peptides in a full scan (m/z 350-2000), with the Orbitrap at FT-resolution spectrum ( $\mathrm{R}=30,000$ FHMW), followed by data dependent MS/MS scan from most intense 10 parent ions with a charge state rejection of one. The signal threshold for triggering an MS/MS event was set to 10,000 counts. The low mass cutoff was set to $100 \mathrm{~m} / \mathrm{z}$. Dynamic exclusion of $30 \mathrm{~s}$ and activation time of $0.1 \mathrm{~s}$ was used. For efficient fragmentation and detection of iTRAQ reporter ions, HCD normalized collision energy of 45 was used. All fragment ions were detected in the Orbitrap $(R=7500$ FHMW). Internal calibration was performed using the ion signal of $(\mathrm{Si}(\mathrm{CH} 3) 2 \mathrm{O}) 6 \mathrm{H}+$ at $\mathrm{m} / \mathrm{z} 445.120025$ as a lock mass. Maximal ion accumulation time allowed on the LTQ Orbitrap was $1 \mathrm{~s}$ for all scan modes; automatic gain control was used to prevent over-filling of the ion trap. 


\section{Database searches and quantitative proteome analysis}

Tandem mass spectra were extracted and charge state deconvoluted by Proteome Discoverer v1.4.0.288 (Thermo Fisher Scientific). All MS/MS samples were analyzed using Mascot (v 2.4.1.0) as search engine node. Mascot was set up to search in NCBInr database (46,742,655 entries), following the application of the restriction for Firmicutes taxonomy. Two missed cleavages were allowed for trypsin digestion, and an error of $0.80 \mathrm{Da}$ for fragment ion mass and $10.0 \mathrm{ppm}$ for a parent ion were tolerated. Oxidation of methionine, acetylation of N-termini and ITRAQ 8-plex modifications were specified as variable modifications, whereas methylation of cysteines was set as static modification. The false discovery rate (FDR) and protein probabilities were calculated by Target Decoy PSM Validator working between 0.01 and 0.05 for strict and relaxed, respectively. For proteins identified with only one single peptide meeting these criteria, we required the Mascot score to be at least 30, and visual verification of fragmentation spectra was done. Identified proteins were grouped by the software to minimize redundancy. For quantitative analysis centroided iTRAQ reporter ion signals were computed and only unique peptides were used for relative protein quantification. iTRAQ reporter ion intensities were normalized to sample 113, that were replicated in the two ITRAQ mixtures.

The statistical analysis was performed on Mass Profile Professional software v. 12.6 from Agilent Technologies. To find differential proteins, a paired 1-way ANOVA test was used selecting a $p<0.05$ and fold change $>1.5$ as cut-off values. Principal component analysis (PCA) was used to evaluate variations in the mean quantity of spots.

\section{Bioinformatic Tools}

On-line databases like NCBI information of each gene, Computational Biology at Oak Ridge National Laboratory (ORNL; http://compbio.ornl.gov/public/section/), DAVID database (https://david.ncifcrf.gov/), KOBAS 2.0 (KEGG Orthology Based Annotation System; http://kobas.cbi.pku.edu. $\mathrm{cn} /$ ) (Xie et al., 2011) were used to assess all the Clusters of Orthologous Groups (COGs) described for O. oeni genes and proteins and metabolic pathways. We analyzed the expression data of arrays with MEV (Multi Experiment View) cluster software using Quality Threshold Clustering (QTC) tool (Heyer et al., 1999). Pearson correlation and a minimum cluster population of the number of genes representative of $10 \%$ were used and a maximum cluster diameter of 0.9 . For construction of Venn diagrams, Venny (an interactive tool for comparing lists with Venn's diagrams, http://bioinfogp.cnb.csic.es/tools/venny/ index.html) was used.

\section{RESULTS AND DISCUSSION}

Functional analysis using comparative transcriptomics and proteomics can provide deeper insight into the molecular mechanisms of adaptation of $O$. oeni to wine stress conditions. The aim of this work was to evaluate which genes and proteins were affected during the adaptation period occurring before the start of MLF. The study was performed with the reference strain
PSU-1 using wine-like medium (WLM) at $\mathrm{pH} 3.4$ and with $12 \%$ of ethanol (v/v). Under these conditions, PSU-1 showed an adaptation period of $8 \mathrm{~h}$ from inoculation until the beginning of MLF. Once L-malate consumption started, MLF was successfully finished in $72 \mathrm{~h}$. The viability of PSU-1 did not decrease during the adaptation period, indicating that there was no detectable cell death of the inoculated population $\left(6.87 \cdot 10^{7} \pm 1.70 \cdot 10^{7}\right.$ $\mathrm{CFU} / \mathrm{mL}$ ).

\section{Global Analysis of Functions Affected during Acclimation to WLM}

In the transcriptomic analysis 1611 expressed sequence tag (EST) were detected. Among the EST that were differently expressed during adaptation, 27 were classified as discontinued or pseudo genes in NCBI, and they were not included in the analysis. Among the analyzed genes showing significant changes along the assay, 314 were over-expressed, whereas 308 genes were down-regulated. They can be consulted in Table S1 in the Supplementary Data. It is worth noting that 52 overexpressed genes and 51 down-regulated genes were annotated as hypothetical proteins (Table S2 in the Supplementary Data).

These 622 genes differently expressed were classified in Clusters Orthologous Groups (COGs) in order to identify the main biological processes influenced by adaptation to wine conditions (Figures 1A,B). Besides, the QTC analysis grouped the differentially expressed genes into six transcriptional profiles (Figure 2). The main functions transcriptionally activated due to inoculation in WLM in O. oeni PSU-1 were translation, ribosomal structure and biogenesis $(\mathrm{J})$ and amino acid transport and metabolism (E) (Figure 1B). The QTC analysis (Figure 2) showed two expression profiles, I and III (65.9 and 13.6\% of over-expressed genes, respectively), in which translation (J) was the most represented function. These two profiles are indicative of an adaptive response since gene transcription increases progressively along adaptation process. The profile II (17.5\% of over-expressed genes) included mostly genes of amino acid metabolism showing an increase in their transcription level between 0.5 and $1 \mathrm{~h}$ which was later decreased. This behavior is indicative of an early-response to WLM stress conditions. Regarding the genes showing an inhibited transcription, carbohydrate metabolism $(\mathrm{G})$ was the main negatively regulated function in PSU-1 during adaptation to WLM (Figure 1B). The genes related to this metabolism mostly showed a constant downregulation and were present in profile IV (Figure 2), representing $62.2 \%$ of total down-regulated genes. Fewer genes were clustered into profile $\mathrm{V}(15.3 \%)$, showing transcriptional repression only at the beginning of the assay $(0.5-1 \mathrm{~h})$. Finally, the profile VI grouped $19.8 \%$ of down-regulated genes which had a progressive repression during the adaptation period.

Proteomic analysis of O. oeni PSU-1 adaptation to WLM conditions was conducted using two techniques: 2D-DIGE and iTRAQ. The PCA analyses to evaluate the variability among samples clearly indicated the presence of three different protein populations 0,1 , and $6 \mathrm{~h}$ (data not shown). The 2D-DIGE results showed between 27 and 62 protein spots along the assay exhibiting differential abundance with statistical significance 


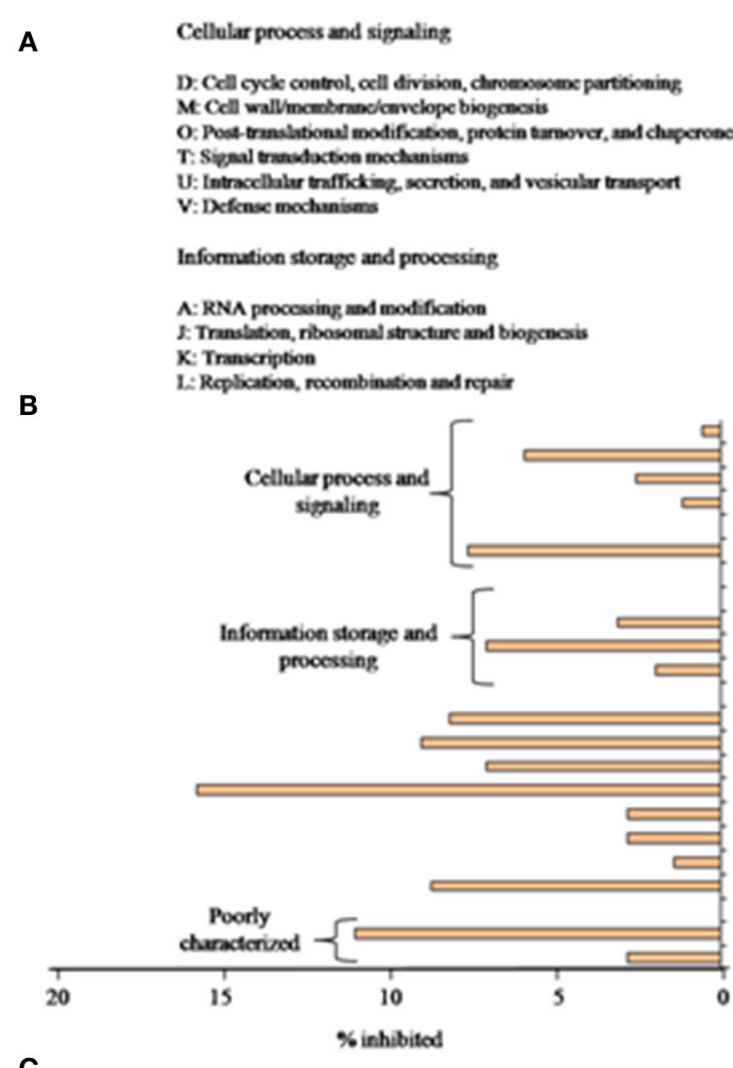

\section{Mctubolism}

C. Encregy production ind coevenion

F: Amimo scid transport ind metabolise

F: Nuckootide transport and metabolism

G: Carbolidydratc transport and motabolisan

H: Cocknyme tringport and metabolism

t: Lipid transpert and moctebolisem

P: teorgenic ion transport and motobolism

Q: Socondary motabolisos biosynthosi, transport, and catabolisem

Poorly characterised

R: Gcncral function prodiction only

S: Function unknown
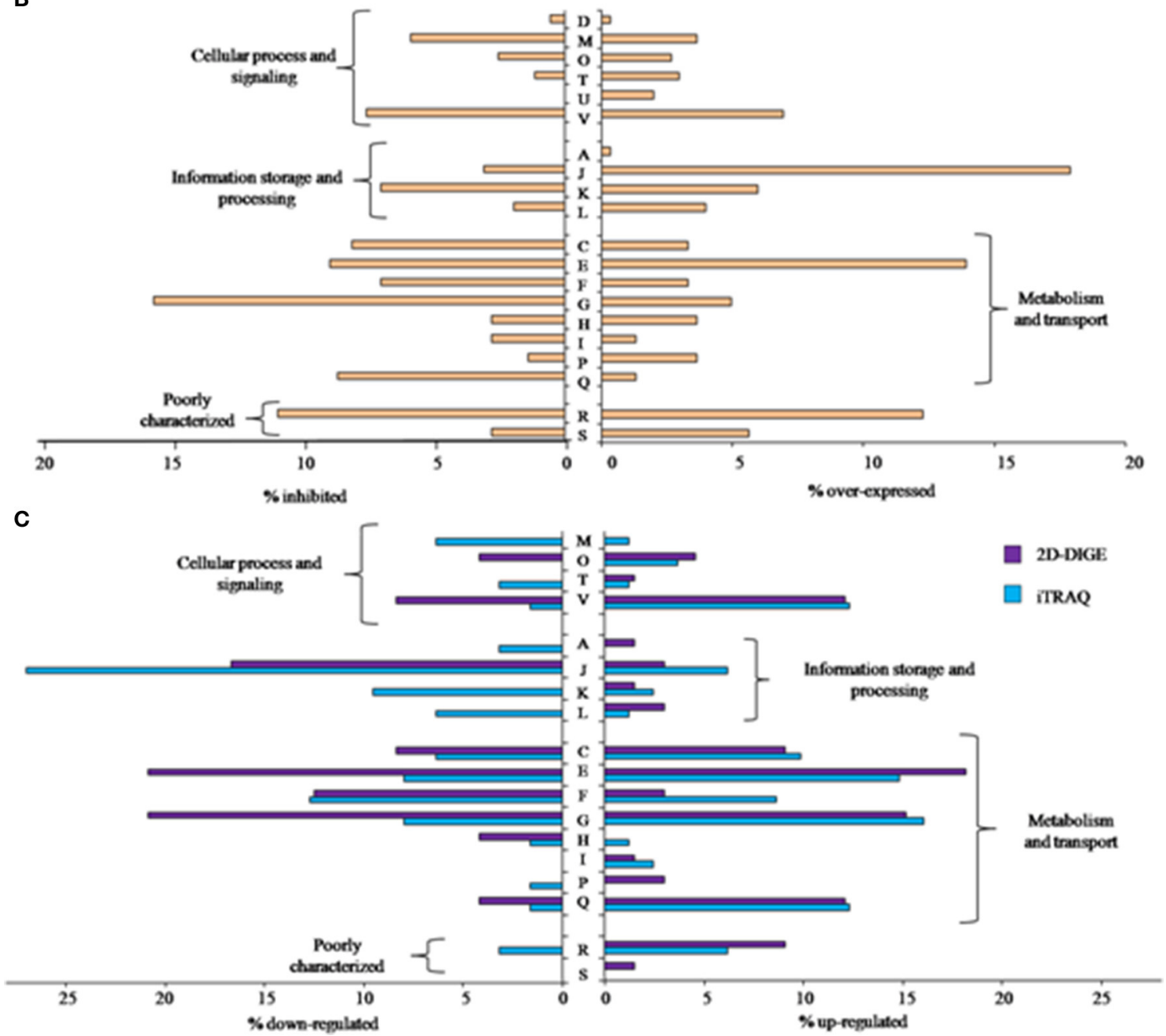

FIGURE 1 | (A) Clusters of Orthologous Groups (COGs) definitions. (B) Percentage of genes of each representative COG significantly over or under-expressed according to transcriptomic analysis. (C) Percentage of proteins of each representative COG showing significant abundance changes, detected by 2D-DIGE or iTRAQ.

( $p \leq 0.05$ ). The maximum differences were observed comparing the samples from 1 and $6 \mathrm{~h}$ after inoculation vs. $0 \mathrm{~h}$. For this reason, the protein identification was carried out only for these samples and also these samples were analyzed using iTRAQ labeling in order to complement 2D-DIGE results. Using 2DDIGE, 33 different proteins could be determined which were not found with iTRAQ. On the other hand, the off-gel technique detected 71 proteins exclusively. At $1 \mathrm{~h}$ there were detected more proteins up regulated than at $6 \mathrm{~h}$, revealing a fast stress proteomic response of the cell against the new environment. All proteomic identification and COG classification from 2D-DIGE and iTRAQ analysis can be consulted in Table S3 (Supplementary Data).

A high percentage of the significantly down-regulated proteins (Figure 1C) belonged to the COG associated to translation, ribosomal structure and biogenesis $(\mathrm{J})$. This is in accordance to previous studies that described the lower abundance of proteins involved in protein synthesis during acid stress in Lactobacillus species (Koponen et al., 2012; Heunis et al., 2014). On the other 


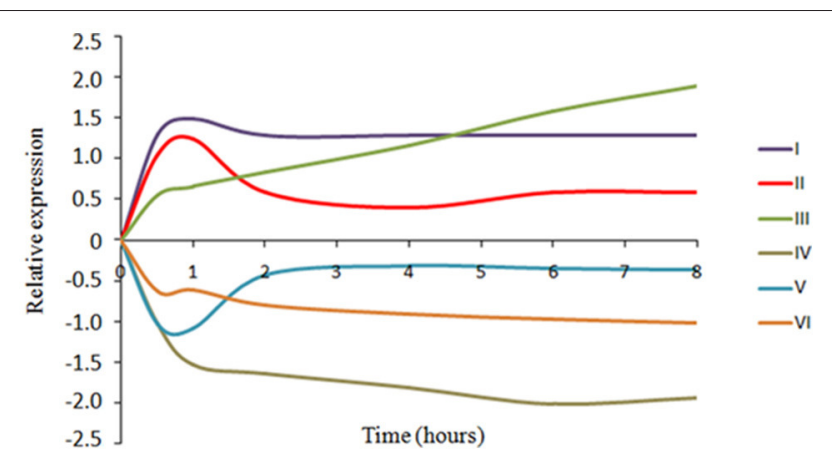

FIGURE 2 | Representative gene expression profiles according to Quality Threshold Clustering (QTC) based on transcriptomic data. An example of each profile is shown. Profile I: OEOE_RS07930 (UDP-N-acetylmuramoyl-tripeptide-D-alanyl-D-alanine ligase); Profile II: OEOE_RS03595 (amino acid ABC transporter substrate-binding protein); Profile III: OEOE_RS05245 (oligoendopeptidase F); Profile IV: OEOE_RS07040 (glycerol-3-phosphate ABC transporter permease); Profile V: OEOE_RS03155 (FOF1 ATP synthase subunit A); Profile VI: OEOE_RS01045 (PTS sugar transporter subunit IIA).

hand, some ribosomal proteins of $50 \mathrm{~S}$ and $30 \mathrm{~S}$ subunits showed an increased abundance in O. oeni PSU-1 after inoculation into WLM. This increase in protein concentration was coincident with an up-regulated gene transcription (Tables 2, 3). Huang et al. (2011) and Koponen et al. (2012) also described the increased abundance of $50 \mathrm{~S}$ and/or $30 \mathrm{~S}$ ribosomal proteins in Lactobacillus species as a mechanism of response to acidic stress. Therefore, certain ribosomal proteins involved in the regulation of translation may play a role in stress response as suggested by Dressaire et al. (2010).

A relevant number of proteins related to amino acid and carbohydrate metabolism (E, G) showed significant variations in abundance (Figure 1C) both increasing or decreasing, being some of them in accordance to the transcriptional response (Tables 2, 3). On the other hand, detected proteins related to defense mechanism (V) and secondary metabolites (Q) showed mostly an increased abundance (Figure 1C).

\section{Main Metabolisms Modified by Wine-Like Conditions}

\section{Malate and Citrate Metabolism}

Three out of the five malate related genes annotated in O. oeni PSU-1 genome were over-expressed: one of the permeases $(m l e P)$, the transporter OEOE_RS06985 -which had a 4fold expression at $1 \mathrm{~h}$ after the inoculation-, and the malate dehydrogenase (mae) (Table 2). The observed transcriptional activation of malate transporters under wine-related conditions were in accordance with previous studies (Labarre et al., 1996) and were indicative of the induction of MLF as a part of stress response. In Augagneur et al. (2007) a significant increase was observed in the abundance of mRNA encoding MleP derived from cells incubated in presence of L-malate at $\mathrm{pH} 4.5$ and 3.2. Similarly, mleP was over-expressed in the microarray performed by Costantini et al. (2015) due to adaptation (1 day) to ethanol 8 and $12 \%$.
In this work it was detected the over-expression of the citrate lyase operon, observing the highest expression $1 \mathrm{~h}$ after the inoculation into WLM (Table 2). The transcriptional activation of $O$. oeni citrate lyase in response to ethanol stress has been previously reported by Olguín et al. (2009). The transcriptional up-regulation of malate transport and citrate consumption could be indicative of the use of L-malate and citrate associated to stress response and as an alternative energy source to sugar metabolism. Significant changes were also observed for genes involved in diacetyl utilization. Diacetyl is the main aromatic compound associated to MLF and is derived from citrate consumption. Diacetyl reductase showed transcriptional inhibition, while its protein abundance increased $6 \mathrm{~h}$ after inoculation into WLM. On the other hand, acetoin reductase was inhibited both at gene and protein level. Diacetyl and acetoin reductases are involved in two reactions of transformation of diacetyl, first into acetoin and then into 2,3-butanediol as the final product. These two reactions involve the oxidation of $\mathrm{NAD}(\mathrm{P}) \mathrm{H}$ and would participate in the maintenance of the cofactor redox balance. Diacetyl metabolism has been described as strain-dependent (Bartowsky and Henschke, 2004). In the studied conditions with PSU-1 strain, diacetyl and acetoin reductases would be initially inhibited, however proteomic data showed the increase in abundance of diacetyl reductase toward the beginning of MLF, which could be correlated to the activation of citrate consumption and the consequent production of diacetyl.

\section{ATPase Activity}

ATPase activity has been associated to MLF (Salema et al., 1996). Cox and Henick-Kling (1989) proposed a chemiosmotic mechanism where energy is produced by the efflux of L-lactate from L-malate degradation. Fortier et al. (2003) described the increase of $\mathrm{F}_{0} \mathrm{~F}_{1}$-ATPase $\beta$ subunit mRNA in response to low $\mathrm{pH}$. However, in this work several genes codifying for other ATPase subunits $(\alpha, \delta, \gamma$, and $\varepsilon)$ were down-regulated before the beginning of MLF (Table 2). Although, in the proteomic study the subunit $\alpha$ was initially down-regulated $(1 \mathrm{~h})$, its abundance increased at $6 \mathrm{~h}$. This could indicate that when cells are longer acclimated to WLM ( $6 \mathrm{~h}$ after inoculation), and closer to the start of L-malate consumption, ATPase activity is increased.

\section{Amino Acid Transport and Metabolism}

It is worth to note the activation of several genes related with peptidase activity and amino acid transport (Table 2). Also, five peptidases were identified in the proteomic analysis, but their abundance varies depending on the protein and the analyzed time. Liu et al. (2010) reported that many of the peptidases seem to be essential for bacterial growth or survival as they are encoded in all LAB genomes, such as PepC, PepN, and PepM, and proline peptidases PepX and PepQ. Currently in PSU-1 genome there are annotated 29 peptidases. Also, related to nitrogen uptake, three permeases involved in nitrogen compounds transport are strongly over-expressed (Table 2) after the inoculation into WLM, reaching the maximum activation at $2 \mathrm{~h}$. Since peptides account for the largest proportion of total nitrogen in wine (Feuillat et al., 1998), these results suggest the relevance of wine nitrogen composition and the ability of $O$. oeni to cope with its 
TABLE 2 | Selection of genes related with relevant metabolisms or functions, differently regulated after inoculation into WLM from the microarray analysis.

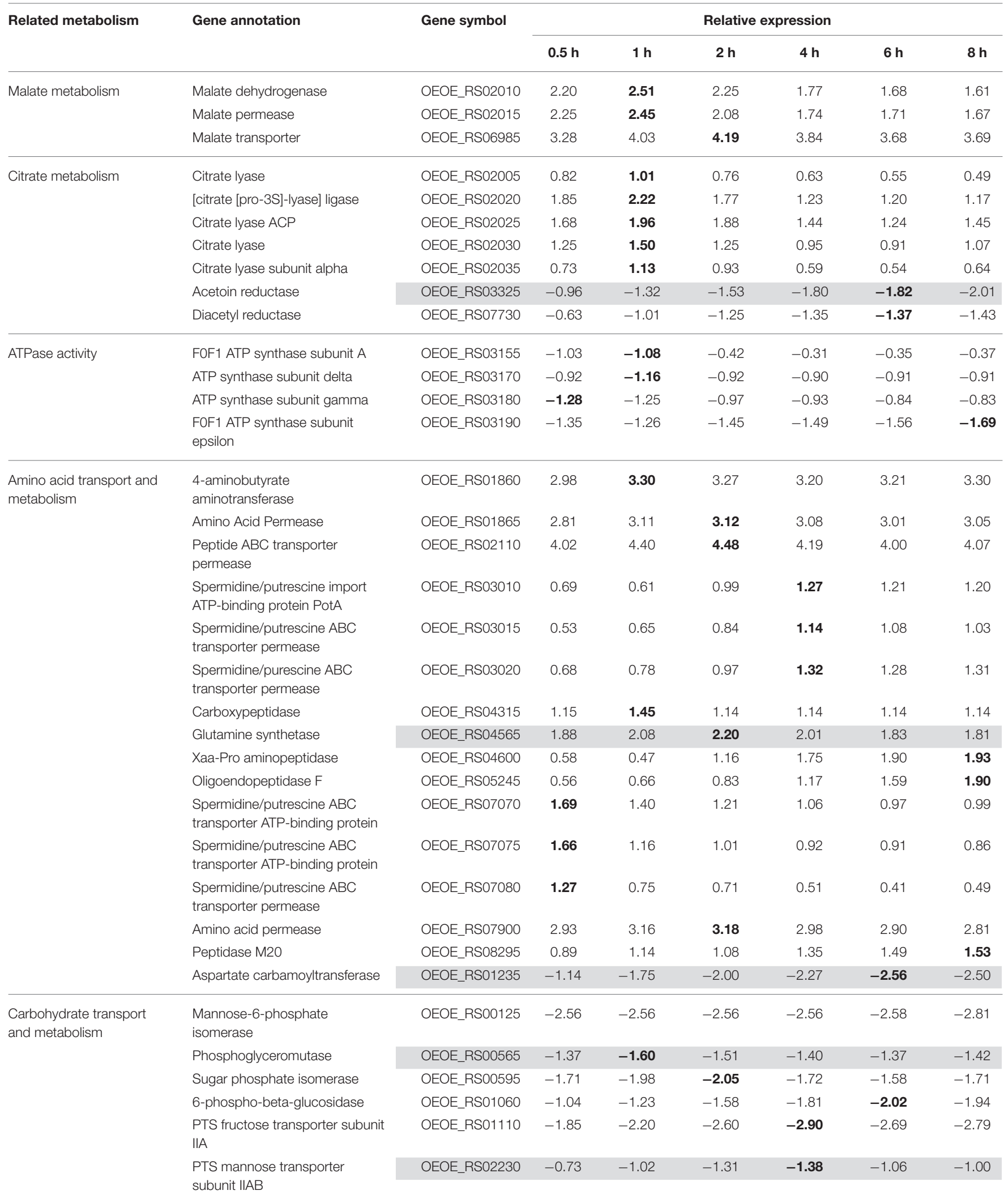


TABLE 2 | Continued

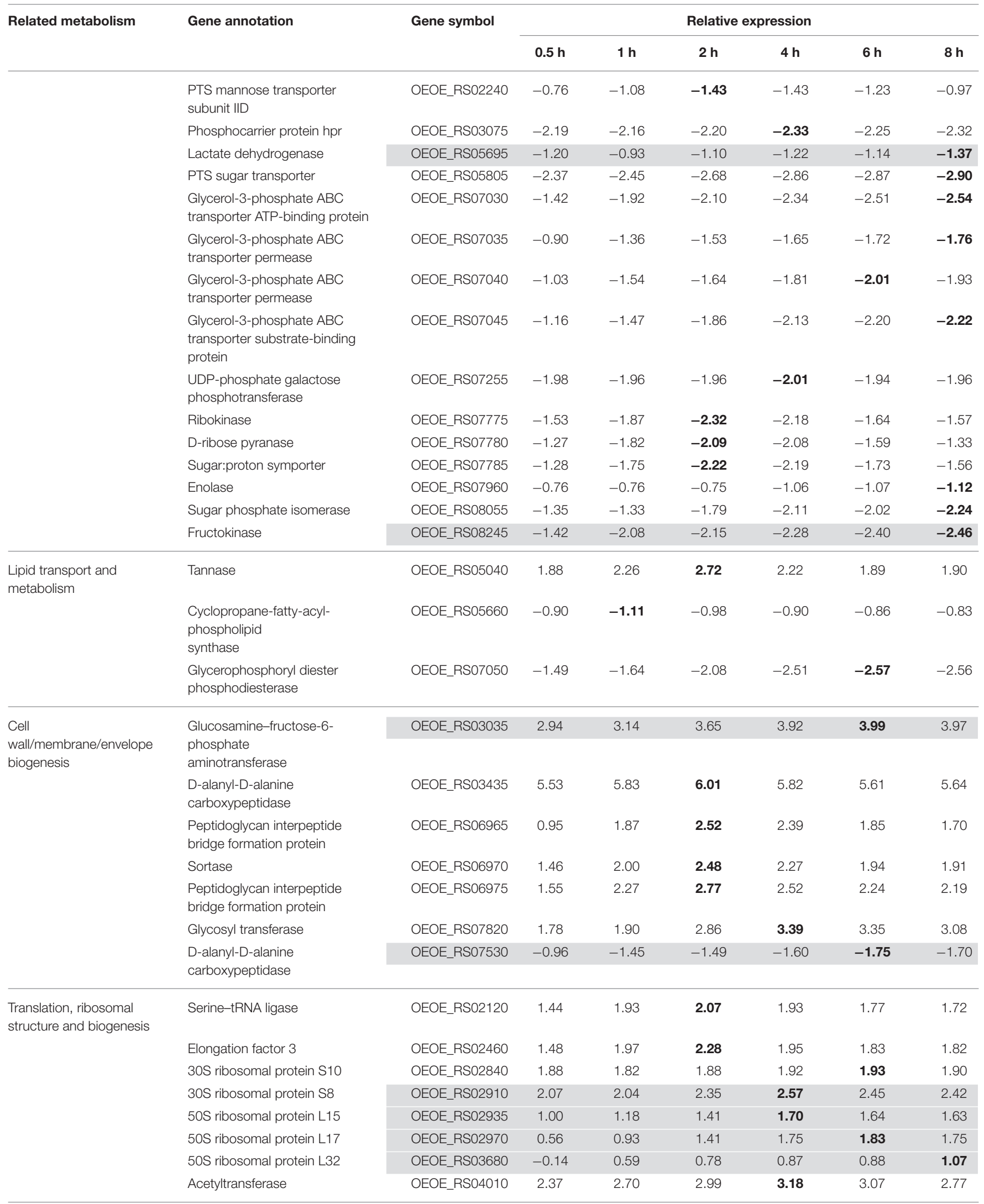


TABLE 2 | Continued

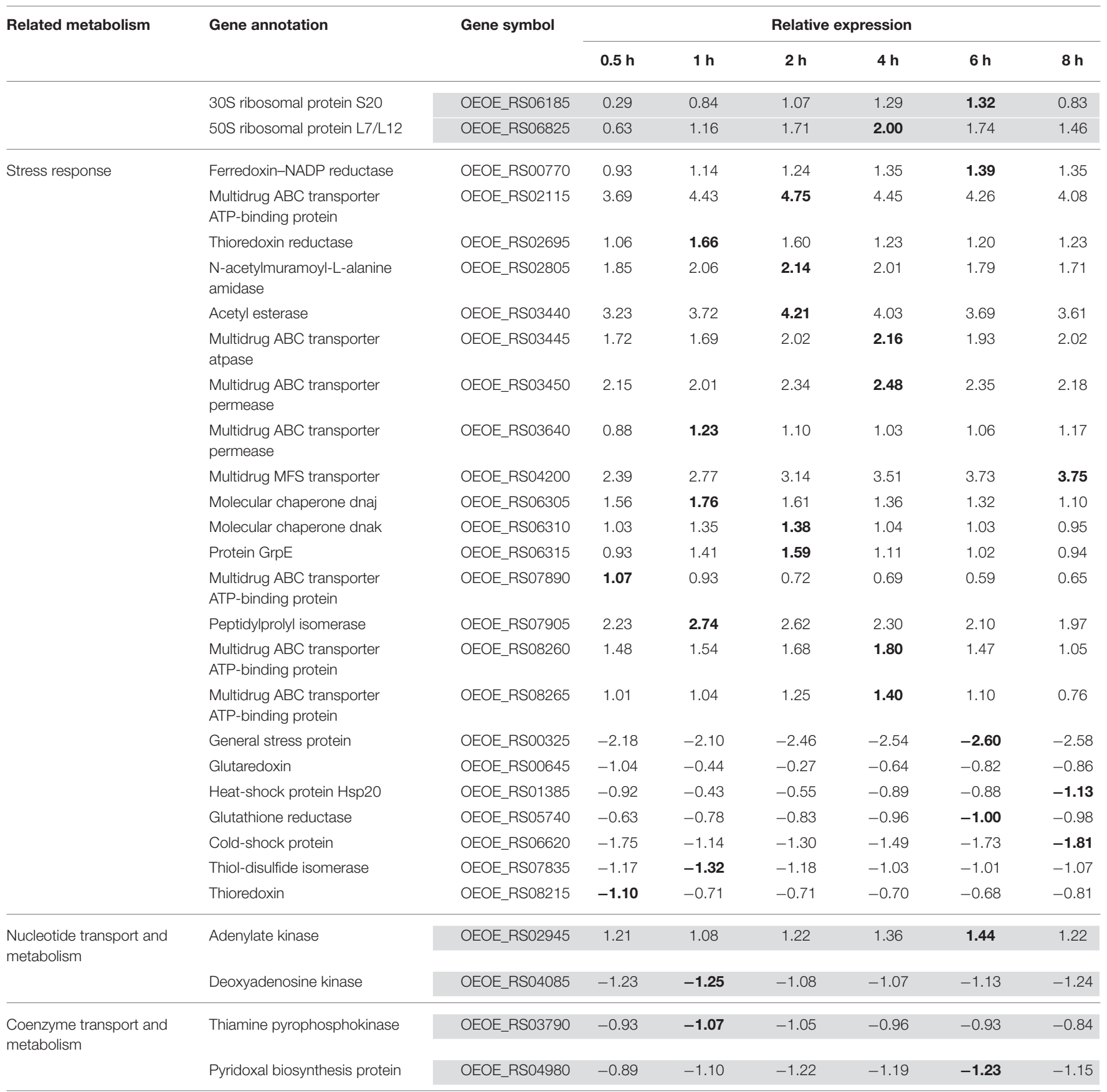

Genes which regulation is coincident with proteomic results are gray highlighted. For each gene, time sample with maximum over- or under-expression is bold highlighted.

environment as reported by Manca de Nadra et al. (1999) and Ritt et al. (2008).

Some genes and proteins related to glutamine and glutamate synthesis, involved in the assimilation and re-distribution of nitrogen within the cell, were up-regulated revealing the key role of nitrogen uptake for $O$. oeni in a poor nutrient media, such as WLM. Glutamine synthetase was upregulated both at gene and protein level. The 4-aminobutyrate aminotransferase gene (OEOE_RS01860), which transforms
GABA into succinate semialdehyde and L-glutamate, was threefold over-expressed during the $8 \mathrm{~h}$ of $O$. oeni PSU-1 adaptation to WLM. GABA can be assimilated as a nitrogen and/or carbon source in bacteria such as Escherichia coli (Bartsch et al., 1990) and Corynebacterium glutamicum (Zhao et al., 2012), but no information is available about LAB in this respect.

Six genes involved in the transport of spermidine/putrescine were over-expressed (Table 2). The uptake of these two 
TABLE 3 | Selection of relevant proteins detected by 2D-DIGE and iTRAQ analysis differently regulated after WLM inoculation at 1 and $6 \mathrm{~h}$.

\begin{tabular}{|c|c|c|c|c|c|c|c|c|}
\hline \multirow[t]{2}{*}{ Related metabolism } & \multirow[t]{2}{*}{ Protein annotation } & \multirow[t]{2}{*}{ Gene symbol } & \multicolumn{4}{|c|}{ Fold change } & \multirow{2}{*}{$\begin{array}{l}\text { Theoretical } \\
\text { Mr (KDa) } \\
\text { DIGE/ITRAQ }\end{array}$} & \multirow{2}{*}{$\begin{array}{c}\text { Pi } \\
\text { DIGE/iTRAQ }\end{array}$} \\
\hline & & & $1 \mathrm{~h}$ & $6 \mathrm{~h}$ & $1 \mathrm{~h}$ & $6 \mathrm{~h}$ & & \\
\hline Malate metabolism & Malate dehydrogenase & OEOE_RS02010 & - & - & -1 & -0.8 & 41.4 & \\
\hline \multirow[t]{2}{*}{ Citrate metabolism } & Acetoin reductase & OEOE_RS03325 & - & - & -1.7 & -0.9 & 27.4 & \\
\hline & & & ND & 1.626 & - & - & 27.4 & 5 \\
\hline ATPase activity & $\begin{array}{l}\text { FOF1 ATP synthase subunit } \\
\text { alpha }\end{array}$ & OEOE_RS03175 & - & - & -1.3 & 0.7 & 56.7 & \\
\hline \multirow[t]{7}{*}{$\begin{array}{l}\text { Amino acid transport } \\
\text { and metabolism }\end{array}$} & $\begin{array}{l}\text { Aspartate } \\
\text { carbamoyltransferase }\end{array}$ & OEOE_RS01235 & -1.31 & $1.53(2)$ & - & - & $35 / 38.9$ & 6.11 \\
\hline & Peptidase M20 & OEOE_RS04760 & 1.3 & 1.36 & 1.3 & 0.7 & $44.1 / 42.1$ & 4.4 \\
\hline & Glutamine amidotransferase & OEOE_RS04955 & - & - & -1 & 0.7 & 27.4 & \\
\hline & Aminopeptidase N & OEOE_RS05080 & ND & -2.14 & 0.9 & -1.1 & 95.1 & 5.1 \\
\hline & $\begin{array}{l}\text { Succinate-semialdehyde } \\
\text { dehdyrogenase }\end{array}$ & OEOE_RS06260 & - & - & 1.6 & 1.1 & 51.5 & \\
\hline & S-ribosylhomocysteine lyase & OEOE_RS07535 & $1.51(3)$ & $1.57(2)$ & 1.8 & 1.5 & 17.7 & 5.3 \\
\hline & Peptidase C69 & OEOE_RS08595 & - & - & 1.9 & 0.9 & 53.5 & \\
\hline \multirow{8}{*}{$\begin{array}{l}\text { Carbohydrate transport } \\
\text { and metabolism }\end{array}$} & Phosphoglycerate mutase & OEOE_RS00565 & -1.57 & -1.53 & - & - & 27.1 & 5.4 \\
\hline & Aldehyde dehydrogenase & OEOE_RS01550 & $1.21(3)$ & $1.59(2)$ & - & - & 52.5 & 4.9 \\
\hline & $\begin{array}{l}\text { Phosphoenol pyruvate-protein } \\
\text { phosphotransferase }\end{array}$ & OEOE_RS03095 & -1.2 & ND & - & - & 63.2 & 5 \\
\hline & Galactose mutarotase & OEOE_RS04920 & - & - & 0.7 & -1.1 & 34.1 & \\
\hline & D-lactate dehydrogenase & OEOE_RS05695 & -1.3 & ND & - & - & 36.5 & 5.74 \\
\hline & UDP-glucose 4-epimerase & OEOE_RS06755 & - & - & 1.1 & 0.7 & 36.9 & \\
\hline & Enolase & OEOE_RS07960 & 1.54 & 1.387 & 0.7 & 1.8 & $48.4 / 47.3$ & 4.6 \\
\hline & Fructokinase & OEOE_RS08245 & -1.2 & ND & - & - & 32.1 & 6.44 \\
\hline \multirow{2}{*}{$\begin{array}{l}\text { Lipid transport and } \\
\text { metabolism }\end{array}$} & ACP S-malonyltransferase & OEOE_RS07670 & - & - & -0.8 & 1.1 & 33.6 & \\
\hline & 2-nitropropane dioxygenase & OEOE_RS07675 & - & - & -1.5 & 0.7 & 33.5 & \\
\hline \multirow{4}{*}{$\begin{array}{l}\text { Cell } \\
\text { wall/membrane/envelope } \\
\text { biogenesis }\end{array}$} & Glucosamine-fructose-6- & OEOE_RS03035 & - & - & 1.7 & 1.1 & 66.2 & \\
\hline & $\begin{array}{l}\text { phosphate } \\
\text { aminotransferase }\end{array}$ & & & & & & & \\
\hline & $\begin{array}{l}\text { Rod shape-determining } \\
\text { protein MreB }\end{array}$ & OEOE_RS03200 & - & - & -1.2 & -1.1 & 40.1 & \\
\hline & $\begin{array}{l}\text { UDP-N-acetylmuramate-L- } \\
\text { alanine } \\
\text { ligase }\end{array}$ & OEOE_RS06110 & - & - & 0.6 & -1.6 & 48.1 & \\
\hline
\end{tabular}


TABLE $3 \mid$ Continued

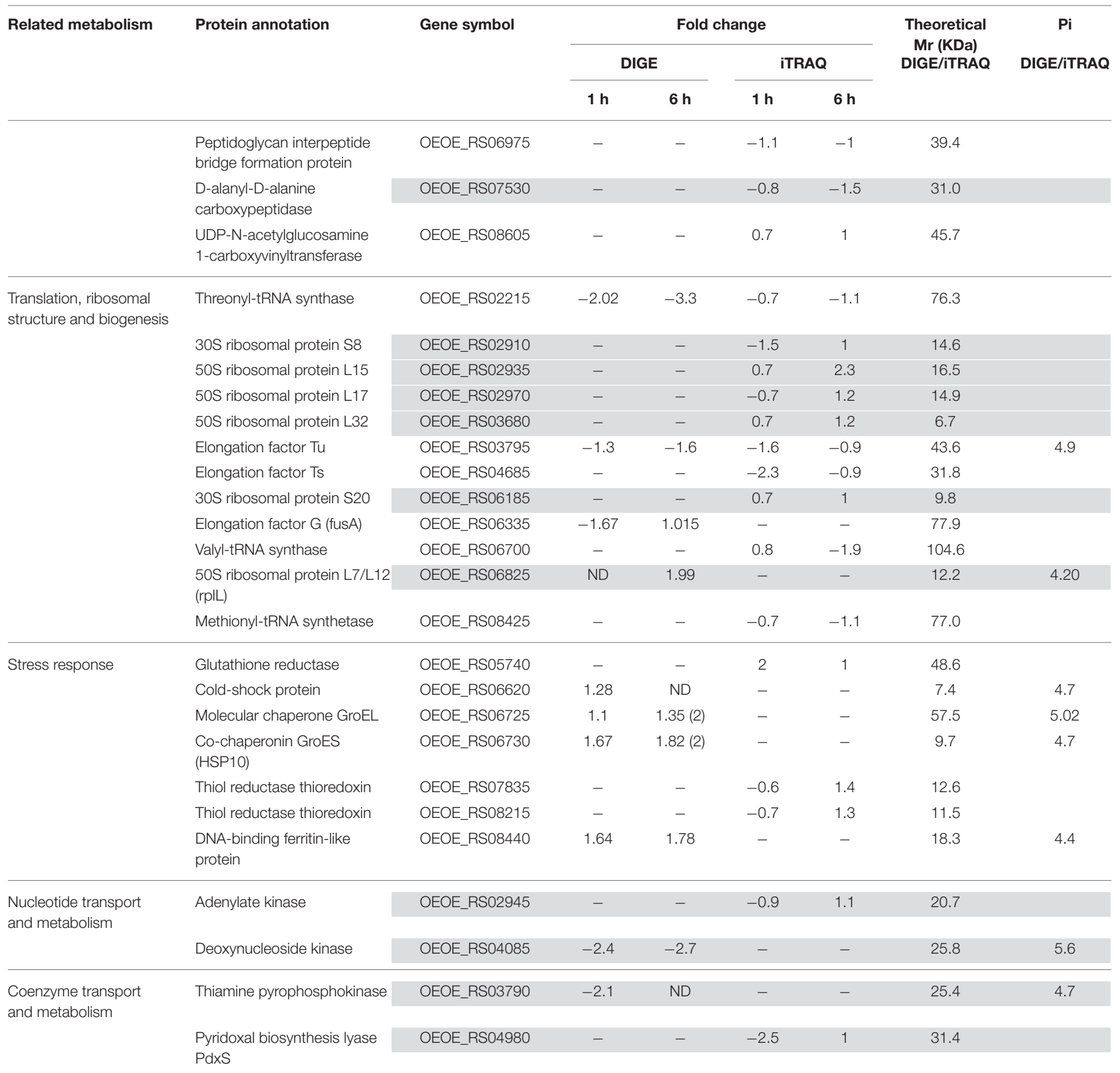

Proteins which regulation is coincident with transcriptomic results are gray highlighted.

polyamines has been associated with an energy-producing state/membrane potential of the cell in E. coli (Kashiwagi et al., 1997). Both putrescine and spermidine protect against oxidative stress (Tkachenko et al., 2001). Olguín et al. (2015) reported that this protective mechanism may also be a target of ethanol damage in an ethanol shock, which would inhibit the uptake of these polyamines. In this case, the adaptation to conditions of WLM resulted in an over-expression of six out of the eight transporters of these polyamines annotated in PSU-1 genome.

\section{Carbohydrate Transport and Metabolism}

Microarray data revealed that sugar transport was repressed (Table 2) in response to WLM conditions. In particular, glycerol-3-phosphate ATP-binding cassette ABC transporters and mannose phosphotransferase transporters (PTS) were downregulated. This inhibition is probably due to the lower availability of sugars in WLM with respect to rich growth medium in which inocula were prepared. A strong transcriptional inhibition of sugar metabolism and transport in response to ethanol was also observed by Olguín et al. (2015). 
Enolase, among others, were strongly up-regulated at low $\mathrm{pH}$ compared with the optimal growth at $\mathrm{pH} 6.8$ (Lee et al., 2008). In this assay, the enolase protein increased in abundance $1 \mathrm{~h}$ after inoculation. On the contrary, the transcriptomic data reported in this work and by Costantini et al. (2015) show the inhibition of enolase gene under wine-like conditions. This suggests that enolase, might be up-regulated at translational level in response to stress. This protein, besides being involved in sugar fermentation, has been related to host tissue adhesion in probiotic bacteria including Lactobacillus plantarum (Castaldo et al., 2009).

\section{Lipid Transport and Metabolism}

The regulation at gene and protein level of lipid metabolism was scarce and, in most of the cases, was down-regulated. For instance, the gene cfa (OEOE_RS05660) which is involved in the conversion of monounsaturated fatty acids to cyclopropane fatty acids (CFAs) was inhibited at $1 \mathrm{~h}$. The increase in $c f a$ transcription was observed in acid- and ethanol-grown cells (Grandvalet et al., 2008; Olguín et al., 2010) after a longer period of stress exposure than in this work, once MLF had started.

\section{Cell Wall/Membrane/Envelope Biogenesis}

Several genes and proteins related to cell envelope biogenesis were over-expressed. One of the genes annotated as D-alanylD-alanine carboxypeptidase (OEOE_RS03435) was 6-fold overexpressed at $2 \mathrm{~h}$ and its sharp over-expression started $0.5 \mathrm{~h}$ after the inoculation into WLM. This gene and OEOE_RS06975 (for peptidoglycan interpeptide bridge formation protein) were also over-expressed in transcriptomic analysis by Costantini et al. (2015), both after adaptation with $12 \%$ of ethanol. However, in the present study, another D-alanyl-D-alanine carboxypeptidase (OEOE_RS07530) showed an opposite behavior, being downregulated both at gene and protein level. Peptidoglycan (PG) is an essential component of the bacterial cell envelope, required for cell shape and stability (Vollmer et al., 2008). A supply of D-amino acids is essential for peptidoglycan synthesis; moreover, D-Ala is the main constituent of wall teichoic acids and lipoteichoic acids, which are polyanionic polymers exclusively found in Gram-positive bacteria (Wecke et al., 2009). Another activated function, both at gene and protein level, was glucosamine:fructose-6-phosphate aminotransferase, which is also involved in cell wall biosynthesis. Cecconi et al. (2009) found a major concentration of glucosamine 6-phosphate aminotransferase in $O$. oeni cells acclimated to ethanol than in not acclimated cells. These results point out the specificity and relevance of some enzymes involved in cell envelope protection against stress challenge.

Three proteins related to cell wall biogenesis were downregulated. Among them, the rod shape-determining protein (MreB), with an actin-like role, was less abundant at 1 and $6 \mathrm{~h}$. These results correlate with the reported information for proteins MreB1 and B2 determining cell shape from L. plantarum 423 which were less abundant in acid-stressed cells (Heunis et al., 2014) and the transcriptional inhibition due to ethanol of other rod shape-determining proteins, such as MreB, in O. oeni (Olguín et al., 2015). Also, microarray analysis revealed the inhibition of three genes (OEOE_RS07265,OEOE_RS03340, and OEOE_RS07010) involved in cell-wall biogenesis, encoding one of them a capsular polysaccharide biosynthesis protein, gene which was described as well by Dimopoulou et al. (2012) as $w z d$. All these down-regulated functions would be targets of the damage caused by factors such as ethanol and low $\mathrm{pH}$.

\section{Translation, Ribosomal Structure, and Biogenesis}

One of the categories showing more significant changes in O. oeni PSU-1 transcriptome and proteome due to WLM conditions was translation related functions. It is worth noting that several $30 \mathrm{~S}$ and $50 \mathrm{~S}$ ribosomal genes were over-expressed like their correspondent proteins. Several ribosomal proteins were up-regulated in Lactobacillus rhamnosus under acidic stress (Koponen et al., 2012). Moreover, in O. oeni in agreement with these observations, Cecconi et al. (2009) reported that adaptation in half strength wine-like medium correlates with the up regulation of some transcription/translation proteins as elongation factor Ts and ribosomal protein 30S. A gene codifying for a ribosomal protein was differentially over expressed between 0 and $1 \mathrm{~h}$ after ethanol addition in O. oeni PSU-1 (Olguín et al., 2015). As well in samples of $O$. oeni adapted to $12 \%$ ethanol, a ribosomal protein was up-regulated (Costantini et al., 2015). Studies with Lactococcus lactis suggest that the regulation of translation has a major role in stress response (Dressaire et al., 2010). According to our results this would also happen in O. oeni.

\section{Stress Response}

As expected, it was observed the activation of chaperon function in response to WLM stress conditions. Some genes, such as grpE, dnaJ, and dnaK, and proteins, like GroEL and GroES (Hsp10), showed up-regulation in PSU-1 after inoculation into WLM (Tables 2, 3). The latter chaperone, Hsp10, is conserved along LAB (Sugimoto et al., 2008). However, Hsp20, the most characterized stress protein in O. oeni (Guzzo et al., 1997, 2000), showed transcriptional inhibition in our assay and no changes in protein concentration. This is in accordance with Costantini et al. (2015), that described the transcriptional activation of $h s p 20$ only in mild ethanol stress ( $8 \%$ ) but the under-expression of this gene with $12 \%$ ethanol, as found in our work. A cold shock protein (OEOE_RS06620) showed increased abundance $1 \mathrm{~h}$ after $O$. oeni PSU-1 inoculation, but its gene expression was inhibited along the assay. This protein could play a role in the early response to wine-related stress but not in the long term adaptation process.

Our data revealed that wine-like conditions caused an increase of proteins involved in oxidative stress protection, related to thioredoxin and glutathione systems. Two out of the three thioredoxins $(\operatorname{tr} x A)$ annotated for PSU-1, OEOE_RS07835, and OEOE_RS08215, were up-regulated $6 \mathrm{~h}$ after inoculation. Also thioredoxin reductase $(\operatorname{tr} x B)$, OEOE_RS02695, and a ferredoxin reductase gene ( $f d r$ : OEOE_RS00770), annotated in NCBI as $\operatorname{tr} x B$ until February 2015, were activated under wine stress conditions. Glutathione reductase (GshR) was significantly more abundant in O. oeni PSU-1 after inoculation into WLM. However, transcriptomic data revealed that some of these genes were inhibited; indicating that translational regulation of these 

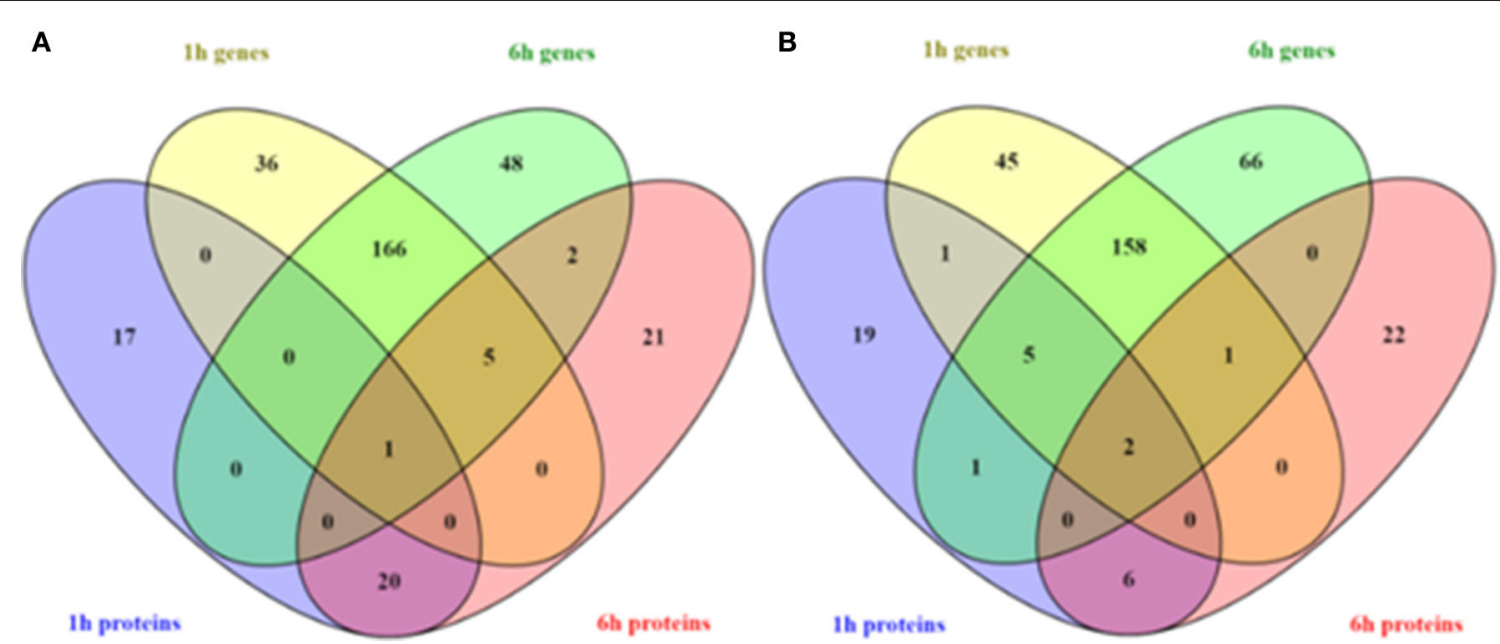

FIGURE 3 | Venn diagram of the number of proteins and genes showing significant changes in abundance and expression, respectively, according to transcriptomic, and proteomic analysis $\mathbf{1}$ and $\mathbf{6} \mathrm{h}$ after the inoculation of $\mathbf{O}$. oeni PSU-1 into WLM. (A) over-expressed genes and up-regulated proteins, (B) under-expressed genes and down-regulated protein. The color of diagram petals match with the colored legends in the figure.

functions would be prevalent under the studied conditions. Our results support the relevance of the thioredoxin and glutathione systems in the adaptation of $O$. oeni to wine related stress. There are few studies regarding thioredoxin in O. oeni (Jobin et al., 1999a; Guzzo et al., 2000; Margalef-Català et al., 2017), thus the role of this mechanism and glutathione system against wine stress is quite unknown.

Among the genes over-expressed related to defense mechanism there were eight multidrug transport genes. $\mathrm{ABC}$ transporters are a major part of the efflux systems involved in the transport of harmful-compounds and cell detoxification (Leverrier et al., 2004).

\section{Evaluation of Omic Data Correlation Real-Time qPCR Validation}

In order to validate the results obtained from the microarray analysis, real-time qPCR was performed with the same RNA from the original microarray experiment. Twenty-two genes, some related to stress response, were selected, taking the RNA sample of time where maximum over- or under- expression had been observed in microarray (Table 1). There was a general accordance between microarray and real-time qPCR data for all the genes tested. Of the 22 genes, 17 were clearly correlated using both techniques. For hsp18 gene higher values by $\mathrm{qPCR}$ were obtained than for microarray data. Finally the four remaining genes (diacylglycerol kinase, PTS sugar, $c f a$ and $\operatorname{tr} x A 2$ ) displayed lower numerical values by qPCR, indicating no significant changes using this technique, while with microarray they were slightly inhibited. Overall, the correlation between real-time $\mathrm{qPCR}$ and microarray was good, suggesting that the microarray gene expression measurements were valid. Moreover, the validation of two thioredoxins (trxA2 and $\operatorname{trx} A 3)$ was useful for the proteomic identification.
Integration of Transcriptomic and Proteomic Analysis

It has been largely reported that the correspondence of transcriptomic and proteomic data is low due to the numerous and complex regulatory mechanisms involved in gene transcription and protein synthesis (Dressaire et al., 2010; Haider and Pal, 2013). In this work, 19 genes presented a correlation with proteomic results (Tables 2, 3). The most relevant, in terms of understanding $O$. oeni stress response, have already been discussed in the text. Venn diagram shown in Figure 3 shows the number of coincident modifications of genes and proteins at different analyzed times vs. time zero. It is worth to note the highest number of coincidences was observed for genes up/down regulated (166 and 158, respectively) 1 and $6 \mathrm{~h}$ after inoculation in WLM. This indicates that most of the transcriptional changes were sustained along the $8 \mathrm{~h}$ assay, before MLF start. However, some genes were only modified at one of the analyzed times, indicating its specific role in early $(1 \mathrm{~h})$ or adaptive $(6 \mathrm{~h})$ response, respectively. Regarding protein changes, the observed pattern was different and many proteins showed modifications only at one of the two analyzed times. However, some proteins maintained the up or down regulation along the assay. Altogether, the data reported illustrates the complexity of $O$. oeni cell regulation and the difficulty of finding specific marker genes and/or proteins associated to stress response.

\section{CONCLUSIONS}

The combined transcriptomic and proteomic study was useful to identify the metabolisms mostly altered due to wine-like conditions. The use of two complementary proteomic techniques allowed the detection of a major number of proteins influenced by stress factors. Our results revealed the relevance of translation regulation and nitrogen uptake as key metabolisms involved in the adaptation of $O$. oeni PSU-1 to wine related stress. Cell wall 
biosynthesis and redox maintenance mechanisms seem to play also a relevant role in the protection of $O$. oeni against cell damage. Finally, sugar metabolism is inhibited in contrast to the transcriptional activation of L-malate transport and citrate consumption before the beginning of MLF.

Most of the molecular modifications occurring during O. oeni adaptation to wine will depend on the strain and/or fermentation conditions. However, the omic analysis allows the identification of the most relevant functions affected by wine-related stress, on which should be focused future research.

\section{AUTHOR CONTRIBUTIONS}

MM, IA: performed the experiments, participated in the acquisition, analysis and interpretation of the data, approved the final version of the paper. AB, CR, JB: supervised the laboratory work, participated in the analysis and interpretation of the data,

\section{REFERENCES}

Augagneur, Y., Ritt, J.-F., Linares, D. M., Remize, F., Tourdot-Maréchal, R., Garmyn, D., et al. (2007). Dual effect of organic acids as a function of external pH in Oenococcus oeni. Arch. Microbiol. 188, 147-157. doi: 10.1007/s00203007-0230-0

Bartowsky, E. J., and Henschke, P. A. (2004). The "buttery" attribute of winediacetyl-desirability, spoilage and beyond. Int. J. Food Microbiol. 96, 235-252. doi: 10.1016/j.ijfoodmicro.2004.05.013

Bartsch, K., Von Johnn-Marteville, A., and Schulz, A. (1990). Molecular analysis of two genes of the Escherichia coli gab cluster: nucleotide sequence of the glutamate:succinic semialdehyde transaminase gene (gabT) and characterization of the succinic semialdehyde dehydrogenase gene (gabD). J. Bacteriol. 172, 7035-7042.

Beltramo, C., Desroche, N., Tourdot-Maréchal, R., Grandvalet, C., and Guzzo, J. (2006). Real-time PCR for characterizing the stress response of Oenococcus oeni in a wine-like medium. Res. Microbiol. 157, 267-274. doi: 10.1016/j.resmic.2005.07.006

Beltramo, C., Grandvalet, C., Pierre, F., and Guzzo, J. (2004). Evidence for multiple levels of regulation of Oenococcus oeni $c l p P$-clpL locus expression in response to stress. J. Bacteriol. 186, 2200-2205. doi: 10.1128/JB.186.7.2200-2205.2003

Betteridge, A., Grbin, P., and Jiranek, V. (2015). Improving Oenococcus oeni to overcome challenges of wine malolactic fermentation. Trends Biotechnol. 33, 547-553. doi: 10.1016/j.tibtech.2015.06.008

Bordas, M., Araque, I., Alegret, J. O., El Khoury, M., Lucas, P., Rozès, N., et al. (2013). Isolation, selection, and characterization of highly ethanol-tolerant strains of Oenococcus oeni from south Catalonia. Int. Microbiol. 16, 113-123. doi: 10.2436/20.1501.01.186

Bordas, M., Araque, I., Bordons, A., and Reguant, C. (2015). Differential expression of selected Oenococcus oeni genes for adaptation in wine-like media and red wine. Ann. Microbiol. 65, 2277-2285. doi: 10.1007/s13213-015-1069-2

Bourdineaud, J.-P. (2006). Both arginine and fructose stimulate $\mathrm{pH}$-independent resistance in the wine bacteria Oenococcus oeni. Int. J. Food Microbiol. 107, 274-280. doi: 10.1016/j.ijfoodmicro.2005.09.011

Bourdineaud, J.-P., Nehmé, B., Tesse, S., and Lonvaud-Funel, A. (2003). The $\mathrm{ftsH}$ gene of the wine bacterium Oenococcus oeni is involved in protection against environmental stress. Appl. Environ. Microbiol. 69, 2512-2520. doi: 10.1128/AEM.69.5.2512-2520.2003

Bourdineaud, J.-P., Nehmé, B., Tesse, S., and Lonvaud-Funel, A. (2004). A bacterial gene homologous to ABC transporters protect Oenococcus oeni from ethanol and other stress factors in wine. Int. J. Food Microbiol. 92, 1-14. doi: 10.1016/S0168-1605(03)00162-4

Cafaro, C., Bonomo, M. G., Rossano, R., Larocca, M., and Salzano, G. (2014). Efficient recovery of whole cell proteins in Oenococcus oeni-a comparison drafted the manuscript, and approved the final version of the paper.

\section{ACKNOWLEDGMENTS}

This work was supported by grants AGL2009-07369ALI and AGL2012-34866ALI from the Spanish Ministry of Economy and Competitiveness. MM is grateful to the pre-doctoral fellowship from the Universitat Rovira i Virgili. JB wish to thank to the Spanish Government for his "Ayuda para la Formación Posdoctoral" research contract.

\section{SUPPLEMENTARY MATERIAL}

The Supplementary Material for this article can be found online at: http://journal.frontiersin.org/article/10.3389/fmicb. 2016.01554 of different extraction protocols for high-throughput malolactic starter applications. Folia Microbiol. (Praha). 59, 399-408. doi: 10.1007/s12223-0140312-8

Castaldo, C., Vastano, V., Siciliano, R. A., Candela, M., Vici, M., Muscariello, L., et al. (2009). Surface displaced alfa-enolase of Lactobacillus plantarum is a fibronectin binding protein. Microb. Cell Fact. 8:14. doi: 10.1186/1475-2 859-8-14

Cecconi, D., Milli, A., Rinalducci, S., Zolla, L., and Zapparoli, G. (2009). Proteomic analysis of Oenococcus oeni freeze-dried culture to assess the importance of cell acclimation to conduct malolactic fermentation in wine. Electrophoresis 30, 2988-2995. doi: 10.1002/elps.200900228

Costantini, A., Rantsiou, K., Majumder, A., Jacobsen, S., Pessione, E., Svensson, B., et al. (2015). Complementing DIGE proteomics and DNA subarray analyses to shed light on Oenococcus oeni adaptation to ethanol in winesimulated conditions. J. Proteomics 123, 114-127. doi: 10.1016/j.jprot.2015. 04.019

Cox, D. J., and Henick-Kling, T. (1989). Chemiosmotic energy from malolactic fermentation. J. Bacteriol. 171, 5750-5752.

De Man, J. C., Rogosa, M., and Sharpe, M. E. (1960). A medium for the cultivation of Lactobacilli. J. Appl. Bacteriol. 23, 130-135. doi: 10.1111/j.13652672.1960.tb00188.x

Desroche, N., Beltramo, C., and Guzzo, J. (2005). Determination of an internal control to apply reverse transcription quantitative PCR to study stress response in the lactic acid bacterium Oenococcus oeni. J. Microbiol. Methods 60, 325-333. doi: 10.1016/j.mimet.2004.10.010

Dimopoulou, M., Hazo, L., and Dols-Lafargue, M. (2012). Exploration of phenomena contributing to the diversity of Oenococcus oeni exopolysaccharides. Int. J. Food Microbiol. 153, 114-122. doi: 10.1016/ j.ijfoodmicro.2011.10.024

Dressaire, C., Laurent, B., Loubière, P., Besse, P., and Cocaign-Bousquet, M. (2010). Linear covariance models to examine the determinants of protein levels in Lactococcus lactis. Mol. Biosyst. 6, 1255-1264. doi: 10.1039/ c001702g

Feuillat, M., Charpentier, C., and Maujean, A. (1998). "Les composés azotés," in Oenologie: Fondements Scientifiques et Techniques, ed Cl. Flanzy (Paris: Lavoisier), 94-116.

Fortier, L.-C., Tourdot-Maréchal, R., Diviès, C., Lee, B. H., and Guzzo, J. (2003). Induction of Oenococcus oeni $\mathrm{H}+$-ATPase activity and mRNA transcription under acid conditions. FEMS Microbiol. Lett. 222, 165-169. doi: 10.1016/S03781097(03)00299-4

Genovese, F., Coïsson, J. D., Majumder, A., Pessione, A., Svensson, B., Jacobsen, S., et al. (2013). An exoproteome approach to monitor safety of a cheese-isolated Lactococcus lactis. Food Res. Int. 54, 1072-1079. doi: 10.1016/j.foodres.2012.12.017 
Görg, A., Weiss, W., and Dunn, M. J. (2004). Current two-dimensional electrophoresis technology for proteomics. Proteomics 4, 3665-3685. doi: 10.1002/pmic.200401031

Grandvalet, C., Assad-García, J. S., Chu-Ky, S., Tollot, M., Guzzo, J., Gresti, J., et al. (2008). Changes in membrane lipid composition in ethanol- and acid-adapted Oenococcus oeni cells: characterization of the cfa gene by heterologous complementation. Microbiology 154, 2611-2619. doi: 10.1099/mic.0.2007/016238-0

Grandvalet, C., Coucheney, F., Beltramo, C., and Guzzo, J. (2005). CtsR is the master regulator of stress response gene expression in Oenococcus oeni. J. Bacteriol. 187, 5614-5623. doi: 10.1128/JB.187.16.5614-5623.2005

Guzzo, J., Delmas, F., Pierre, F., Jobin, M.-P., Samyn, B., Van Beeumen, J., et al. (1997). A small heat shock protein from Leuconostoc oenos induced by multiple stresses and during stationary growth phase. Lett. Appl. Microbiol. 24, 393-396. doi: 10.1046/j.1472-765X.1997.00042.x

Guzzo, J., Jobin, M. P., Delmas, F., Fortier, L. C., Garmyn, D., Tourdot-Maréchal, R., et al. (2000). Regulation of stress response in Oenococcus oeni as a function of environmental changes and growth phase. Int. J. Food Microbiol. 55, 27-31. doi: $10.1016 /$ S0168-1605(00)00209-9

Haider, S., and Pal, R. (2013). Integrated analysis of transcriptomic and proteomic data. Curr. Genomics 14, 91-110. doi: 10.2174/1389202911314020003

Hecker, M., Schumann, W., and Völker, U. (1996). Heat-shock and general stress response in Bacillus subtilis. Mol. Microbiol. 19, 417-428. doi: 10.1046/j.13652958.1996.396932.x

Hecker, M., and Völker, U. (1998). Non-specific, general and multiple stress resistance of growth-restricted Bacillus subtilis cells by the expression of the sigmaB regulon. Mol. Microbiol. 29, 1129-1136. doi: 10.1046/j.13652958.1998.00977.x

Heunis, T., Deane, S., Smit, S., and Dicks, L. M. T. (2014). Proteomic Profiling of the acid stress response in Lactobacillus plantarum 423. J. Proteome Res. 13, 4028-4039. doi: 10.1021/pr500353x

Heyer, L. J., Kruglyak, S., and Yooseph, S. (1999). Exploring expression data: identification and analysis of coexpressed genes. Genome Res. 9, 1106-1115. doi: $10.1101 /$ gr.9.11.1106

Huang, G., Li, C., and Cao, Y. (2011). Proteomic analysis of differentially expressed proteins in Lactobacillus brevis NCL912 under acid stress. FEMS Microbiol. Lett. 318, 177-182. doi: 10.1111/j.1574-6968.2011.02257.x

Jobin, M. P., Delmas, F., Garmyn, D., Diviès, C., and Guzzo, J. (1997). Molecular characterization of the gene encoding an 18-kilodalton small heat shock protein associated with the membrane of Leuconostoc oenos. Appl. Environ. Microbiol. $63,609-614$

Jobin, M. P., Garmyn, D., Diviès, C., and Guzzo, J. (1999a). Expression of the Oenococcus oeni trxA gene is induced by hydrogen peroxide and heat shock. Microbiology 145, 1245-1251.

Jobin, M. P., Garmyn, D., Diviès, C., and Guzzo, J. (1999b). The Oenococcus oeni $c l p X$ homologue is a heat shock gene preferentially expressed in exponential growth phase. J. Bacteriol. 181, 6634-6641.

Kashiwagi, K., Shibuya, S., Tomitori, H., Kuraishi, A., and Igarashi, K. (1997). Excretion and uptake of putrescine by the PotE protein in Escherichia coli. J. Biol. Chem. 272, 6318-6323. doi: 10.1074/jbc.272.10.6318

Koponen, J., Laakso, K., Koskenniemi, K., Kankainen, M., Savijoki, K., Nyman, T. A., et al. (2012). Effect of acid stress on protein expression and phosphorylation in Lactobacillus rhamnosus GG. J. Proteomics 75, 1357-1374. doi: 10.1016/j.jprot.2011.11.009

Labarre, C., Guzzo, J., Cavin, J. F., and Diviès, C. (1996). Cloning and characterization of the genes encoding the malolactic enzyme and the malate permease of Leuconostoc oenos. Appl. Environ. Microbiol. 62, 1274-1282.

Lee, K., Lee, H. G., Pi, K., and Choi, Y. J. (2008). The effect of low pH on protein expression by the probiotic bacterium Lactobacillus reuteri. Proteomics 8, 1624-1630. doi: 10.1002/pmic.200700663

Leverrier, P., Vissers, J. P. C., Rouault, A., Boyaval, P., and Jan, G. (2004). Mass spectrometry proteomic analysis of stress adaptation reveals both common and distinct response pathways in Propionibacterium freudenreichii. Arch. Microbiol. 181, 215-230. doi: 10.1007/s00203-003-0646-0

Liu, M., Bayjanov, J. R., Renckens, B., Nauta, A., and Siezen, R. J. (2010). The proteolytic system of lactic acid bacteria revisited: a genomic comparison. $B M C$ Genomics 11:36. doi: 10.1186/1471-2164-11-36
Lonvaud-Funel, A. (1999). Lactic acid bacteria in the quality improvement and depreciation of wine. Antonie van Leeuwenhoek. Int. J. Gen. Mol. Microbiol. 76, 317-331.

Manca de Nadra, M. C., Farías, M. E., Moreno-Arribas, V., Pueyo, E., and Polo, M. (1999). A proteolytic effect of Oenococcus oeni on the nitrogenous macromolecular fraction of red wine. FEMS Microbiol. Lett. 174, 41-47. doi 10.1111/j.1574-6968.1999.tb13547.x

Margalef-Català, M., Stefanelli, E., Araque, I., Wagner, K., Felis, G. E., Bordons, A., et al. (2017). Variability in gene content and expression of the thioredoxin system in Oenococcus oeni. Food Microbiol. 61, 23-32. doi: 10.1016/j.fm.2016.08.005

Mehmeti, I., Kiran, F., and Osmanagaoglu, O. (2011). Comparison of three methods for determination of protein concentration in lactic acid bacteria for proteomics studies. J. Biotechnol. 10, 2178-2185. doi: 10.5897/AJB 10.1881

Mills, D. A., Rawsthorne, H., Parker, C., Tamir, D., and Makarova, K. (2005). Genomic analysis of Oenococcus oeni PSU-1 and its relevance to winemaking. FEMS Microbiol. Rev. 29, 465-475. doi: 10.1016/j.femsre.2005.04.011

Napoli, A., Aiello, D., Aiello, G., Cappello, M. S., Di Donna, L., Mazzotti, F., et al. (2014). Mass spectrometry-based proteomic approach in Oenococcus oeni enological starter. J. Proteome Res. 13, 2856-2866. doi: 10.1021/pr40 12798

Olguín, N., Bordons, A., and Reguant, C. (2009). Influence of ethanol and pH on the gene expression of the citrate pathway in Oenococcus oeni. Food Microbiol. 26, 197-203. doi: 10.1016/j.fm.2008.09.004

Olguín, N., Bordons, A., and Reguant, C. (2010). Multigenic expression analysis as an approach to understanding the behaviour of Oenococcus oeni in wine-like conditions. Int. J. Food Microbiol. 144, 88-95. doi: 10.1016/j.jiffoodmicro.2010.08.032

Olguín, N., Champomier-Vergès, M., Anglade, P., Baraige, F., Cordero-Otero, R., Bordons, A., et al. (2015). Transcriptomic and proteomic analysis of Oenococcus oeni PSU-1 response to ethanol shock. Food Microbiol. 51, 87-95. doi: $10.1016 /$ j.fm.2015.05.005

Ritt, J.-F., Guilloux-Benatier, M., Guzzo, J., Alexandre, H., and Remize, F. (2008). Oligopeptide assimilation and transport by Oenococcus oeni. J. Appl. Microbiol. 104, 573-580. doi: 10.1111/j.1365-2672.2007.03585.x

Ross, P. L., Huang, Y. N., Marchese, J. N., Williamson, B., Parker, K., Hattan, S., et al. (2004). Multiplexed protein quantitation in Saccharomyces cerevisiae using amine-reactive isobaric tagging reagents. Mol. Cell. Proteomics 3, 1154-1169. doi: 10.1074/mcp.M400129MCP200

Salema, M., Capucho, I., Poolman, B., San Romão, M. V., and Dias, M. C. (1996). In vitro reassembly of the malolactic fermentation pathway of Leuconostoc oenos (Oenococcus oeni). J. Bacteriol. 178, 5537-5539.

Shevchenko, A., Wilm, M., Vorm, O., and Mann, M. (1996). Mass spectrometric sequencing of proteins silver-stained polyacrylamide gels. Anal. Chem. 68, 850-858. doi: 10.1021/ac950914h

Silveira, M. G., Baumgärtner, M., Rombouts, F. M., and Grac, M. (2004). Effect of adaptation to Ethanol on Cytoplasmic and membrane protein profiles of Oenococcus oeni. App. Environ. Microbiol. 70, 2748-2755. doi: 10.1128/AEM.70.5.2748-2755.2004

Spano, G., and Massa, S. (2006). Environmental stress response in wine lactic acid bacteria: beyond Bacillus subtilis. Crit. Rev. Microbiol. 32, 77-86. doi: 10.1080/10408410600709800

Stefanelli, E. (2014). Stress Response and Intraspecific Diversity in Oenococcus oeni. $\mathrm{PhD}$ thesis. Università degli Studi di Verona, Verona.

Sugimoto, S., Abdullah-Al-Mahin, and Sonomoto, K. (2008). Molecular chaperones in lactic acid bacteria: physiological consequences and biochemical properties. J. Biosci. Bioeng. 106, 324-336. doi: 10.1263/jbb. 106.324

Sumby, K. M., Grbin, P. R., and Jiranek, V. (2012). Validation of the use of multiple internal control genes, and the application of real-time quantitative PCR, to study esterase gene expression in Oenococcus oeni. Appl. Microbiol. Biotechnol. 96, 1039-1047. doi: 10.1007/s00253-012-4409-1

Tkachenko, A. G., Pshenichnov, M. R., and Nesterova, L. Y. (2001). Putrescine as a factor protecting Escherichia coli against oxidative stress. Microbiology 70 , 422-428. doi: 10.1023/A:1010430126763 
Unlü, M., Morgan, M. E., and Minden, J. S. (1997). Difference gel electrophoresis: a single gel method for detecting changes in protein extracts. Electrophoresis 18, 2071-2077. doi: 10.1002/elps.11501 81133

Vandesompele, J., De Preter, K., Pattyn, F., Poppe, B., Van Roy, N., De Paepe, A., et al. (2002). Accurate normalization of real-time quantitative RTPCR data by geometric averaging of multiple internal control genes. Genome Biol. 3:RESEARCH0034. doi: 10.1186/gb-2002-3-7-research 0034

Vollmer, W., Joris, B., Charlier, P., and Foster, S. (2008). Bacterial peptidoglycan (murein) hydrolases. FEMS Microbiol. Rev. 32, 259-286. doi: 10.1111/j.15746976.2007.00099.x

Wecke, J., Perego, M., and Fischer, W. (2009). d-Alanine deprivation of Bacillus subtilis Teichoic Acids is without effect on cell growth and morphology but affects the autolytic activity. Microb. Drug Resist. 2, 123-129. doi: $10.1089 / \mathrm{mdr} .1996 .2 .123$

Xie, C., Mao, X., Huang, J., Ding, Y., Wu, J., Dong, S., et al. (2011). KOBAS 2.0: a web server for annotation and identification of enriched pathways and diseases. Nucleic Acids Res. 39(Suppl. 2), W316-W322. doi: 10.1093/nar/ gkr483
Zhao, Z., Ding, J. Y., Ma, W. H., Zhou, N. Y., and Liu, S. J. (2012). Identification and characterization of $\gamma$-Aminobutyric acid uptake system GabPCg (NCgl0464) in Corynebacterium glutamicum. Appl. Environ. Microbiol. 78, 2596-2601. doi: 10.1128/AEM.07406-11

Conflict of Interest Statement: The authors declare that the research was conducted in the absence of any commercial or financial relationships that could be construed as a potential conflict of interest.

The reviewer EET and handling Editor declared their shared affiliation, and the handling Editor states that the process nevertheless met the standards of a fair and objective review.

Copyright (c) 2016 Margalef-Català, Araque, Bordons, Reguant and BautistaGallego. This is an open-access article distributed under the terms of the Creative Commons Attribution License (CC BY). The use, distribution or reproduction in other forums is permitted, provided the original author(s) or licensor are credited and that the original publication in this journal is cited, in accordance with accepted academic practice. No use, distribution or reproduction is permitted which does not comply with these terms. 